\title{
PUBLICACIONES SOBRE FILOLOGÍA GRIEGA EN ESPAÑA (2015)
}

Helena Rodríguez Somolinos

ILC - CSIC. Madrid

helena.rsomolinos@cchs.csic.es

\section{RESUMEN}

Bibliografía relativa a Filología Griega publicada en España en 2015.

Palabras Clave: Filología Griega; Bibliografía: España

\section{Abstract}

Bibliography concerning Greek Philology published in Spain in 2015.

KEY WORDS: Greek Philology; Bibliography: Spain

\section{Índice general}

1. ACTAS DE CONGRESOS. HOMENAJES. VOLÚMENES COLECTIVOS

2. AUTORES ANTIGUOS. EDICIONES, TRADUCCIONES Y ESTUDIOS

3. HISTORIA DE LA LITERATURA

4. LINGÜÍSTICA GRIEGA. MÉTRICA

5. MICENOLOGÍA

6. EPIGRAFÍA. PAPIROLOGÍA. NUMISMÁTICA

7. HISTORIA DE LOS TEXTOS

8. HISTORIA. CULTURA. SOCIEDAD

9. RELIGIÓN. MITOLOGÍA

10. CRISTIANISMO

11. FILOSOFÍA. CIENCIA

12. PERVIVENCIA. HUMANISMO. HISTORIA DE LA FILOLOGÍA

13. DICCIONARIOS. REPERTORIOS. OTROS INSTRUMENTOS

14. DIDÁCTICA 



\section{REVISTAS}

AEA

AEF

AFAM

AM

AM-E

Antesteria

Arys

$\mathrm{AuOr}$

Bandue

Cal.Ren.

CCO

CFCG

CFCL
Archivo Español de Arqueología. Madrid, CSIC, Departamento de Arqueología y Prehistoria. http://aespa.revistas.csic.es/index.php/aespa

Anuario de Estudios Filológicos. Cáceres. Universidad de Extremadura. Facultad de Filosofía y Letras. https://anuariodeestudiosfilologicos.wordpress.com/

Anuari de Filologia. Clàssica et Medievalia. Universitat de Barcelona. Facultat. de Filologia. www.raco.cat/index.php/AFAM/index

Analecta Malacitana. Universidad de Málaga. Facultad de Filosofía y Letras. Sección de Filología. www.anmal.uma.es/

Analecta Malacitana Electrónica. Universidad de Málaga. Facultad de Filosofía y Letras. Sección de Filología. www.anmal.uma.es/

Antesteria. Debates de Historia Antigua. Jóvenes Investigadores del Departamento de Historia Antigua de la Universidad Complutense. http://ucm.academia. edu/RevistaAntesteria

Arys. Antigüedad: religiones y sociedades. Universidad de Huelva. Servicio de Publicaciones. www.uhu.es/publicaciones/ojs/index.php/arys

Aula Orientalis. Revista de Estudios del Próximo Oriente Antiguo. Institut Interuniversitari d'Estudis del Pròximo Orient Antic. Sabadell (Barcelona). Editorial Ausa. www.aulaorientalis.org/

Bandue. Revista de la Sociedad Española de Historia de las Religiones. Madrid, Editorial Trotta. http://secr.es/publicaciones/bandue/

Calamus Renascens. Revista de Humanismo y tradición clásica. Alcañiz, Cádiz, Instituto de Estudios Humanísticos, Universidad de Cádiz.www.estudioshumanisticos.org/publicaciones.php

Collectanea Christiana Orientalia. Universidad de Córdoba. Facultad de Filosofía y Letras. http://www.uco.es/collectanea/

Cuadernos de Filología Clásica. Estudios Griegos e Indoeuropeos. Universidad Complutense de Madrid. Facultad de Filología. http://revistas.ucm.es/index. $\mathrm{php} / \mathrm{CFCG}$

Cuadernos de Filología Clásica. Estudios Latinos. Universidad Complutense de Madrid. Facultad de Filología. http://revistas.ucm.es/index.php/CFCL 
$E B$

EC

EClás.

EH

EI

ELEA

Emerita

Epos

Faventia

FI

$F N$

Fortunatae

Gallaecia

Gerión

Habis

HAnt.

Helmantica
Estudios Bíblicos. Madrid. Universidad San Dámaso, Asociación Bíblica Española. http://www.sandamaso.es/tienda/revistas/105-informacion-de-la-revista.html

Exemplaria Classica. Departamento de Filologías Integradas. Facultad de Humanidades. Universidad de Huelva. www.uhu.es/publicaciones/ojs/index.php/ exemplaria/index

Estudios Clásicos. Madrid, Sociedad Española de Estudios Clásicos. http://www. estudiosclasicos.org/estudios-clasicos/

Estudios Humanísticos. Filología. Universidad de León. Facultad de Filosofía y Letras. http://www.filosofiayletras.unileon.es/estudios-humanisticos-filologia/

Estudios Interlingüísticos. Asociación de Jóvenes Lingüistas. http://estudiosinterlinguisticos.com

Estudios de Lenguas y Epigrafía Antiguas. Valencia. Real Academia de Cultura Valenciana.

Emerita. Revista de Lingüística y Filología Clásica. Madrid. C.S.I.C. Instituto de Lenguas y Culturas del Mediterráneo y Oriente Próximo. http://emerita. revistas.csic.es/index.php/emerita

Epos. Revista de Filología. Madrid. Universidad Nacional de Educación a Distancia. Facultad de Filología. http://revistas.uned.es/index.php/EPOS

Faventia. Universitat Autònoma de Barcelona. Facultat de Lletres. Dpto. de Filología Clásica. http://ddd.uab.es/record/21?ln=ca

Florentia Iliberritana. Revista de Estudios de Antigüedad Clásica. Universidad de Granada. www.ugr.es/ hantigua/florentia.html

Filología Neotestamentaria. Universidad de Córdoba. Facultad de Filosofía y Letras. http://www.bsw.org/filologia-neotestamentaria/

Fortunatae. Revista canaria de filología, cultura y humanidades clásicas. Universidad de la Laguna. Departamento de Filología Clásica y Arabe. http://publica. webs.ull.es/publicaciones/detalle/revista-fortvnatae/fortunatae-revista-canaria-de-filologia-cultura-y-humanidades-clasicas/

Gallaecia. Universidad de Santiago de Compostela. Departamento de Historia I. http://www.usc.es/revistas/index.php/gallaecia

Gerión. Universidad Complutense de Madrid. Departamento de Historia Antigua. http://revistas.ucm.es/index.php/GERI

Habis. Universidad de Sevilla. http://institucional.us.es/habis/

Hispania Antiqua. Revista de Historia Antigua. Universidad de Valladolid. Departamento de Historia Antigua. www.publicaciones.uva.es/Buscador.aspx?txtBusqueda=HISPANIA\%20ANTIQ\&txtFamilia=Humanidades\%20/\%20Revistas

Helmantica. Revista de Filología Clásica y Hebrea. Univ. Pontificia de Salamanca. https://www.intranet.upsa.es/publica/publicaciones.pl?method=detalleRevista\&id $=4$ 
'Ilu

Interlingüística

Ítaca

Lucentum

Methodos

MHNH

Minerva

Myrtia

Palaeohispanica

Paremia

Ph.Canar.

Polis

Pyrenae

R.S.E.L.

SEBarc.

SHHA
'Ilu. Revista de Ciencias de las Religiones. Universidad Complutense de Madrid. Instituto Universitario de Ciencias de las Religiones. http://revistas.ucm.es/ index.php/ILUR

Interlingüística Revista de la Asociación de Jóvenes Lingüistas (sustituida desde 2012 por EI).

Ítaca. Quaderns Catalans de Cultura Clàsica. Barcelona. Institut d' Estudis Catalans. http://publicacions.iec.cat/PopulaFitxa.do?moduleName=revistes_cientifiques $\&$ subModuleName $=\&$ idColleccio $=58$

Lucentum. Anales de la Universidad de Alicante. Prehistoria, Arqueología e Historia antigua. Universidad de Alicante. https://web.ua.es/es/lucentum/

Methodos. Revista de didàcticadelsestudisclàssics. Paideia. Grup de Didàctica de les Llengües i la Cultura Clàssiques de la Universitat Autònoma de Barcelona. http://pagines.uab.cat/methodos/

MHNH Revista internacional de investigación sobre Magia y Astrología antiguas. Málaga, Centro de Ediciones de la Diputación de Málaga. http://webdeptos. uma.es/dep_griego/MHNH/index.htm

Minerva. Revista de Filología Clásica. Universidad de Valladolid. Departamento de Filología Clásica. http://minerva.blogs.uva.es/

Myrtia. Universidad de Murcia. http://revistas.um.es/myrtia/index

Palaeohispanica. Revista sobre lenguas y culturas de la Hispania Antigua. Zaragoza. Institución Fernando el Católico. http://ifc.dpz.es/publicaciones/periodica/id/18

Paremia. Boletín de Investigaciones Paremiológicas. Madrid. Asociación Cultural Independiente (Sigüenza) Universidad Complutense. Sersa Ediciones.

Philologica Canariensia. Universidad de Las Palmas de Gran Canaria. Facultad de Filología. http://ojsspdc.ulpgc.es/ojs/index.php/PhilCan/index

Polis. Revista de ideas y formas políticas de la Antigüedad Clásica. Universidad de Alcalá de Henares. http://www1.uah.es/publicaciones/catal.asp

Pyrenae. Revista de Prehistòria i Antiguitat de la Mediterrània Occidental. Barcelona. Universitat de Barcelona. Facultat de Geografia i Història. Departament de Prehistòria, Història Antiga y Arqueologia. http://www.pyrenae.com/ home/index.php?lang=ca

Revista Española de Lingüística. Organo de la Sociedad Española de Lingüística. Madrid. www.sel.edu.es/presentacion-revista

Sylloge Epigraphica Barcinonensis. Universitat de Barcelona. www.raco.cat/ index.php/SEBarc/index

Studia Historica. Historia Antigua. Universidad de Salamanca. Facultad de Geografía e Historia. Departamento de Prehistoria y arqueología. http://campus. usal.es/ preharq/studia.html 
$S P h V$

Talia dixit

Tempus

Thamyris

Tycho

Veleia

Zephyrus
Studia Philologica Valentina. Universidad de Valencia. http://www.uv.es/sphv/

Talia dixit. Revista Interdisciplinar de Retórica e Historiografía. Grupo de Investigación Arenga. Universidad de Extremadura. http://www.eweb.unex.es/eweb/ arengas/taliadixit.htm

Tempus. Revista de Actualización científica. Madrid, Ediciones Clásicas. www. edicionesclasicas.com

Thamyris. Nova series. Revista de Didáctica de Cultura Clásica. Delegación de Málaga de la S.E.E.C., Departamentos de Filología Griega y Latina de la Universidad de Málaga. www.thamyris.uma.es

Tycho. Revista de iniciación en la investigación del teatro clásico grecolatino y su tradición. Universidad de Valencia. www.uv.es/tycho/

Veleia. Revista de Prehistoria, Historia Antigua, Arqueología y Filología Clásica. Vitoria. Universidad del País Vasco. Instituto de Ciencias de la Antigüedad. http://www.ehu.eus/ojs/index.php/Veleia

Zephyrus. Revista de Prehistoria e Historia Antigua. Universidad de Salamanca. http://campus.usal.es/ revistas_trabajo/index.php/0514-7336 


\section{ACTAS DE CONGRESOS. HOMENAJES. VOLÚMENES COLECTIVOS}

Adivinos, magos, brujas, astrólogos:

Martínez García, Ó. - Montero Montero, M. (eds.): Adivinos, magos, brujas, astrólogos. Aspectos populares de las religiones del Mundo Antiguo. Madrid, SEEC, 2015.

Bestiaris i metamorfosis:

Narro, A. - Pomer, J. J. (eds.): Bestiaris i metamorfosis a les literatures clàssiques i la seua tradició. Ámsterdam - Las Palmas, Hakkert, 2015.

De Orfeo a David Lynch:

Broncano, F. - Hernández de la Fuente, D. (eds.): De Orfeo a David Lynch: mito, simbolismo y recepción. Ensayos y ficciones, Madrid, Escolar y Mayo, 2015.

E barbatulis puellisque:

Movellán Luis, M. - Verano Liaño, R. (eds.): «E barbatulis puellisque». Actas del II congreso Ganímedes de investigadores noveles de filología clásica. 2015.

El alimento de los dioses:

García Fernández, F. J. - Lozano Gómez, F. - Pereira, A. (eds.): El alimento de los dioses. Sacrificio y consumo de alimentos en las religiones antiguas. Sevilla, Universidad, 2015.

En Grecia y Roma V:

A. Pociña Pérez, A. - García González, J. M. (eds.): En Grecia y Roma V: hombres notables. Granada, Universidad, 2015.

Estudios en honor del profesor Vitalino Valcárcel:

Ruiz Arzálluz, L. (coord.): Estudios de Filología e Historia en honor del profesor Vitalino Valcárcel. 2 volúmenes. Vizcaya, Universidad del País Vasco, 2014.

\section{Europa Renascens:}

Macías Villalobos, C. - Maestre Maestre, J.M. - Martos Montiel (eds.): Europa Renascens. La cultura clásica en Andalucía y su proyección europea. Zaragoza, Pórtico, 2015.

Fantasmas, aparecidos y muertos sin descanso:

Aguirre Castro, M. Delgado Linacero, C. - González-Rivas, A. (eds.): Fantasmas, aparecidos y muertos sin descanso. Madrid, Abada editores, 2014.

Fueron felices y comieron perdices:

Santana Henríquez, G. (coord.): Fueron felices y comieron perdices. Gastronomía y Literatura. Madrid, Ediciones Clásicas, 2014.

Galeno. Lengua, composición literaria, léxico, estilo:

López Férez, J.A. (eds.): Galeno. Lengua, composición literaria, léxico, estilo. Madrid, Ediciones clásicas, 2015.

Género y enseñanza de la historia:

Domínguez Arranz, A. - Marina Sáez, R.M. (eds.): Género y enseñanza de la historia. Silencios y ausencias en la construcción del pasado. Madrid, Sílez, 2015. 
Homenaje a Fremiot Hernández González

Fortunatae 25, 2014.

Homenaje a Ignacio Rodríguez Alfageme:

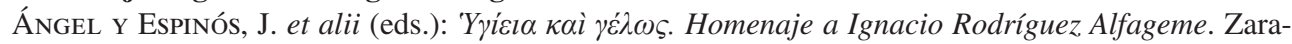
goza, Pórtico, 2015.

Humanismo y pervivencia del mundo clásico V:

Maestre Maestre, J. M. et alii (eds.): Humanismo y pervivencia del mundo clásico V: Homenaje al profesor Juan Gil. 5 vols. Madrid, CSIC, 2015.

\section{Ianua Classicorum:}

De la Villa Polo, J. - Cañizares Ferriz, P. - Falque Rey, E. - González Castro, J. F. - Siles Ruiz, J. (eds.): Ianua Classicorum. Temas y formas del mundo clásico. Actas del XIII Congreso Español de Estudios Clásicos. Madrid, Sociedad Española de Estudios Clásicos, 2015.

Imaginarios científicos:

Olmos, P. - Pezzoli, F. (eds.): Imaginarios científicos. Conocimiento, narraciones y utopías. Madrid, Ediciones Clásicas, 2015.

La mano del escriba:

Torallas Tovar, S. (eds.): La mano del escriba. Recorrido por los tesoros manuscritos de la Abadía de Montserrat. Barcelona, Publicacions de l'Abadia de Montserrat, 2015.

La vida a escena:

Alvar Ezquerra, A. (coord.): La vida a escena. Ayer y hoy del teatro clásico. Alcalá de Henares, Universidad, 2015.

Los papiros mágicos griegos:

SuÁrez de la Torre, E. - Blanco, M. - Chronopoulou, E. (eds.): Los papiros mágicos griegos: entre lo sublime y lo cotidiano. Madrid, Dykinson, 2015.

Nómos ágraphos - Nómos éngraphos

Alvarado Planas, J. et alii: Nómos ágraphos - Nómos éngraphos. Estudios de derecho griego y romano. Madrid, Dykinson, 2015.

Orientalística en tiempos de crisis:

Bernabé, A. - Álvarez-Pedrosa, J. A. (eds.): Orientalística en tiempos de crisis. Actas del VI Congreso nacional del Centro de Estudios del Próximo Oriente. Zaragoza, Pórtico, 2015.

Realidad, ficción y autenticidad en el mundo antiguo:

Velázquez, I. - Martínez, J. (eds.): Antigüedad y Cristianismo XIX.Realidad, ficción y autenticidad en el mundo antiguo: La investigación ante documentos sospechosos. Murcia, Universidad, 2015.

Sócrates. La muerte del hombre más justo:

Zamora, J. M. - Garrocho, D. S. (eds.): Sócrates. La muerte del hombre más justo. Madrid, Avarigani, 2015. 
Studia Angelo Urbano dicata:

López Quero, S. - Maestre Maestre, J. M. (eds.): Studia Angelo Urbano dicata. Alcañiz - Madrid, Instituto de Estudios Humanísticos - Federación Andaluza de Estudios Clásicos, 2015.

\section{Studia Classica Caesaraugustana:}

Vela Tejada, J. - Fraile Vicente, J. F. - Sánchez mañas, C. (eds.): Studia Classica Caesaraugustana.Vigencia y presencia del mundo clásico hoy. XXV años de Estudios Clásicos en la Universidad de Zaragoza. Monografías de Filología Griega 25. Zaragoza, Universidad, 2015.

Texto, traducción, ¡acción!:

Quiroga Puertas, A. J. (eds..): Texto, traducción, ;acción! El legado clásico en el cine. Prólogo de F. Lillo. Almería, Editorial Círculo Rojo, 2014.

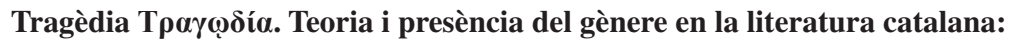

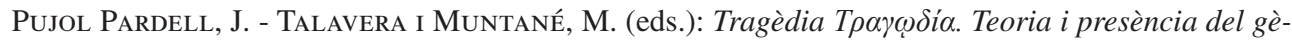
nere en la literatura catalana. Barcelona, Universitat de Barcelona, 2015.

\section{AUTORES ANTIGUOS. EDICIONES, TRADUCCIONES, ESTUDIOS}

\section{Achilles Tatius}

Homar, R.: “Les descripcions d'animals a la novel·la d'Aquil·les Taci: més enllà d'unes pauses?", Bestiaris i metamorfosis 37-50.

- "Quan les Paraules no mouen a COMPassió. Tragèdia, dansa i gestualitat a la novel-la d'Aquil-les Taci (III 10-11)”, Ítaca 30, 2014, p. 77-94.

Vinagre Lobo, M.Á.: “Aquiles Tacio y los progymnásmata: la sýnkrisis”, Ianua Classicorum II 303310.

\section{Acta Apostolorum Apocrypha}

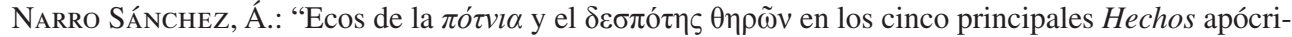
fos de los apóstoles", Minerva 28, 2015, 185-220.

\section{Aelianus}

Eliano: Historias curiosas. Traducción de J. M. Cortés Copete. Madrid, Valdemar, 2015.

Redondo, J.: "Paradoxografia i cientifisme a la Història dels animals de Claudi Elià", Bestiaris i metamorfosis 189-206.

\section{Aeschylus}

CitTI, V.: “Aesch. Suppl. 825-902”, Ítaca 30, 2014, p. 9-28.

EsQuilo, Coéforas. Introducción, guía didáctica y traducción de E. Flor Jiménez. Madrid, KRK Ediciones, 2015.

- La Orestea. Estudio preliminar, edición, traducción y notas de M. García Valdés. Madrid, Ediciones Clásicas, 2015.

- Prometeo encadenado. Fragmentos de otras tragedias sobre Prometeo. Edición y traducción de E. Calderón Dorda. Madrid, CSIC, 2015.

Fialho, M.C.: "Ecos de Sete contra Tebas em Rei Édipo de Sófocles”, Homenaje a Ignacio Rodríguez Alfageme 215-224.

Garriga, C.: “L'Absolució d'Orestes i l'angoixa de l'espectador”, Ítaca 30, 2014, p. 43-58. 
Garrigasait Colomés, R.: L' hàbit de la dificultat: Wilhelm von Humboldt i Carles Riba davant l'Agamèmnon d'Èsquil. Barcelona, Mateo Triguero Rubia., 2015.

GASTI, H.: "Aeschylus' Agamemnon 782-974: The poetics of deixis", CFCG 25, 2015, 115-123.

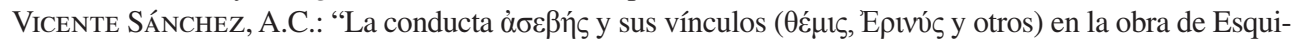
lo", CFCG 25, 2015, 125-155.

\section{Africanus, Sextus Iulius}

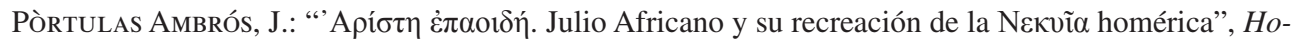
menaje a Ignacio Rodríguez Alfageme 705-716.

\section{Agatho tragicus}

LuZón MARTín, P.: “El Agatón de Aristóteles”, Ianua Classicorum II 207-214.

\section{Alexander Aphrodisiensis}

Gatsioufa, P.: "El códice sacromontano del Comentario a la Metafísica de Alejandro de Afrodisíade. Filiación textual", CFCG 25, 2015, 301-316.

González Calderón, J. F.: Historia de la tradición textual del comentario de Alejandro de Afrodisias a los Tópicos de Aristóteles. Tesis doctoral. Universidad Carlos III de Madrid, 2015. https://e-archivo.uc3m.es/handle/10016/20670?locale-attribute=en

\section{Anacreo}

Moya del Baño, F. - Gallego Moya, E.: "La vida de Anacreonte y el trabajo `filológico’ de Quevedo", Homenaje a Ignacio Rodríguez Alfageme 599-620.

\section{Anonymus}

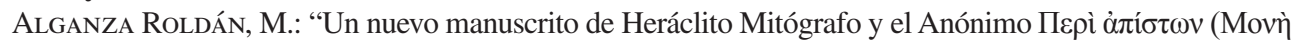

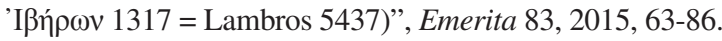

\section{Anthologia Graeca}

Martins de Jesús, C.: "La tumba de la Musa: alrededor de Safo en la Antología griega", FI 26, 2015, $61-79$.

— “Madre o monstruo? Medea en la Antología Griega”, Myrtia 30, 20 5, I45-I66.

\section{Antigonus Nicaenus}

HeILEN, S.: "Sexuality and eroticism in the Horoscopes of Antigonus of Nicaea", MHNH 14, 2014, 119-146.

\section{Antiochus Atheniensis astrologus}

PÉREZ JimÉnEZ, A.: "Antiochi De stellarum in locis thematis significationibus fragmentum epicum. Edición, traducción española y comentario", $M H N H$ 14, 2014, 217-290.

\section{Antipho}

PASTOR ANDRÉs, H. F.: "Léxico y metáforas agonísticas en el orador Antifonte: nuevas consideraciones", SHHA 33, 2015, 13-37.

\section{Aphthonius rhetor}

Arcos Pereira, T. - García de Paso Carrasco, M. D.: "La traducción al latín de algunos términos griegos y su repercusión en los comentarios a los Aphthonii Progymnasmata", CFCL 35, 2015, 319-336. 
Apollonius Pergaeus

ACERBI, F.: "Delle utopie matematiche. La reforma impossibile di Apollonio", Imaginarios científicos 105-114.

\section{Apollonius Rhodius}

Gallé Cejudo, R. J.: "Partenio de Nicea, el motivo de Tarpeya y la Fundación de Lesbos atribuida a Apolonio de Rodas", Studia Angelo Urbano dicata 219-231.

\section{Appianus}

BARAY, L.: "Le ‘brigand lusitanien' reconsidéré. Analyse du problème de la terre chez Appien”, Gerión 33, 2015, 229-260.

BigGi, N.: "Una nota ad App. Hann. 149”, Myrtia 30, 2015, 291-292.

Gozalbes Cravioto, E.: “Sobre el rey Syfax de Numidia”, SHHA 33, 2015, 69-96.

\section{Archimedes}

Strathern, P.: Arquímedes y la palanca. En 90 minutos. Madrid, Akal, 2014.

\section{Aristophanes}

Bartoletti, T. J.: "Oráculos burlados y enigmas cómicos en Caballeros de Aristófanes", Emerita 83, 2015, 23-45.

Bilbao Ruiz, J.: "La cita de poetas líricos en los escolios de Acarnienses", Estudios en honor del profesor Vitalino Valcárcel 137-150.

— "La crítica de la tragedia euripidea en los escolios de Aristófanes: Schol. Ach. 443", Ianua Classicorum II 67-73.

Konstan, D.: "Sócrates en Nubes de Aristófanes", Sócrates. La muerte del hombre más justo 171-198.

Labiano Ilundain, M.: "Las islas: ¿comedia aristofánica o comedia media?”, Realidad, ficción y autenticidad en el mundo antiguo 321-336.

López Castellón, E.: "La confusión de Aristófanes", Sócrates. La muerte del hombre más justo 61-84.

Martínez Díez, A.: "El Aristófanes de Marcelino Menéndez Pelayo", Homenaje a Ignacio Rodríguez Alfageme 493-502.

Mastromarco, G.: "Nota scenica alle Ecclesiazuse de Aristofane", Homenaje a Ignacio Rodríguez Alfageme 521-528.

Méndez Dosuna, J.: “El enchytrismós de niños expósitos en la antigua Grecia: ¿realidad o ficción?”, Homenaje a Ignacio Rodríguez Alfageme 543-554.

Shere, M. J.: "Las críticas contra la aristocracia en la comedia temprana de Aristófanes", Habis 46, 2015, 33-49.

Silva, M. F.: "Dinheiro e sociedade. Aristófanes, Pluto", Homenaje a Ignacio Rodríguez Alfageme 753-764.

\section{Aristoteles}

Aguirre, J.: Dialéctica y Filosofía primera. Lectura de la Metafísica de Aristóteles. Zaragoza, Universidad de Zaragoza, 2015.

ARISTóteles: El hombre de genio y la melancolía (problema XXX). Traducción de C. Serna. Barcelona, Acantilado, 2014.

- Ética a Nicómaco. Barcelona, Olmak Trade, 2015.

- Retórica. Barcelona, Olmak Trade, 2015.

ARISTòTIL: De l'ànima. Introducció, text grec revisat, traducció i notes de M.Candel. Col-lecció dels Clàssics Grecs i Llatins 409. Barcelona, Fundació Bernat Metge, 2015. 
Bermúdez Ramiro, J. - Montañés Gómez, R.: "La traducción al latín de Alessandro Pazzi en el comentario a la Poética de Aristóteles de Francesco Robortello: criterios para su evaluación”, Europa Renascens 623-636.

BRENTANO, F.: La psicología de Aristóteles con especial atención a la doctrina del entendimiento agente. Seguida de un apéndice sobre la actividad del Dios aristotélico. Madrid, Universidad San Dámaso, 2015.

Clusa CAPell, J.: Aristóteles. Justicia y eudaimonía. Tesis doctoral. Universidad Autónoma de Barcelona, 2015. www.tdx.cat/bitstream/10803/322802/1/jcc1de1.pdf

De Miguel Mora, C.: “Aristóteles, Escalígero y Weinberg”, Humanismo y pervivencia del mundo clásico $V$, vol.III 1339-1349.

DíEz Yáñez, M.: El noble virtuoso. Recepción de la ética aristotélica en la Castilla tardomedieval y renacentista. Tesis Doctoral. Universidad Complutense de Madrid, 2015. http://eprints.ucm.es/33240/

Fuente Cornejo, T. - Llera Fueyo, L. A.: "Observaciones a las anotaciones a la Poética de Aristóteles del humanista valenciano Pedro Juan Núñez", Humanismo y pervivencia del mundo clásico $V$, vol.III 1247-1255.

Gambra, J. M. - Oriol Salgado, M.: Lógica aristotélica. Madrid, Dykinson, 2015.

Garrocho Salcedo, D.S.: Aristóteles. Una ética de las pasiones, Madrid, Avarigani Editores, 2015.

GonzÁlez CALderón, J.F.: Historia de la tradición textual del comentario de Alejandro de Afrodisias a los Tópicos de Aristóteles. Tesis doctoral. Universidad Carlos III de Madrid, 2015. https://e-archivo. uc3m.es/handle/10016/20670?locale-attribute=en

González Cruz, I.: El libro perdido de Aristóteles. Madrid, Dykinson, Año: 2015.

Llera Fueyo, L. A.: "Notas al griego de las Anotaciones a la Poética de Aristóteles de Pedro Juan Núñez", Ianua Classicorum III 379-386.

Lukasiewicz, J.: Sobre el principio de contradicción en Aristóteles. Prólogo de A. G. Vigo. Traducción de R. Rovira. Madrid, Encuentro, 2015.

Luzón Martín, P.: "El Agatón de Aristóteles", Iапиa Classicorum II 207-214.

Minecan, A.M.C.: Recepción de la física de Aristóteles por Tomás de Aquino. Finitud, necesidad, vacío, unicidad del mundo y eternidad del universo. Tesis doctoral, Universidad Complutense de Madrid, 2015. http://eprints.ucm.es/33744/

Morata Senar, E.: El mundo de Aristóteles: comentario de la Metafísica de Aristóteles y otros libros suyos. Madrid, Nuevos escritores, 2015.

Navarro Sánchez, F.: "Aristóteles Latinus en las Questiones super libro de animalibus Aristotelis de Pedro Hispano", Ianua Classicorum III 287-294.

Ortega Muñoz, J. F.: Tratado de Filosofía primera. Nuevos estudios de Metafísica a partir de Aristóteles. Málaga, Universidad, 2014.

Rovira, R.: Repertorio de definiciones aristotélicas. Madrid, Escolar y Mayo, 2015.

Solana Pujalte, J. E. - García Pinilla, I. J.: "Erratas y correcciones manuscritas de autor en la traducción latina de la Política de Aristóteles de Juan Ginés de Sepúlveda editada por Michel de Vascosan (París, 1548) (II): los escolios”, Humanismo y pervivencia del mundo clásico V, vol.II 1019-1036.

Strathern, P.: Aristóteles en 90 minutos. Madrid, Siglo XXI, 2015.

\section{Arrianus historicus}

García Bueno, C.: "Una traducción latina anónima de los comentarios de Arriano a Epicteto", Ianua Classicorum III 355-361.

\section{Artemidorus Ephesius}

Bossina, L.: "Il cosidetto 'papiro di Artemidoro'. Dalla parte degli scettici", Realidad, ficción y autenticidad en el mundo antiguo 285-320. 
Pajón Leyra, I.: "Vicisitudes de un geógrafo: el papiro de Artemidoro y la discusión acerca de su autenticidad", Realidad, ficción y autenticidad en el mundo antiguo271-284.

\section{Athenaeus}

ATENEU DE NÀUCRATIS: El sopar del serudits, vol. I: llibre I (epítome). Introducció, text revisat, traducció i notes de R. Montañés Gómez, J. Sanchis Llopis i J. Pérez Asensio. Col-lecció dels Clàssics Grecs i Llatins 406. Barcelona, Fundació Bernat Metge, 2015.

Pino CAmpos, L. M.: "La literatura simposíaca en Grecia: Ateneo de Náucratis y El erudito del banquete", Fueron felices y comieron perdices 193-264.

\section{Batrachomyomachia}

ToRné I TeIXIDó, R.: "Sobre la mixtura de géneros en la Batracomiomaquia", Ianua Classicorum II 287-294.

\section{Biblia Graeca}

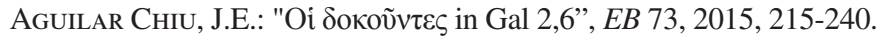

Astorga Guerra, P.: Anagnórisis en la historia de José (Gn 37-50). Una aproximación desde la narratología cognitiva. Estella, Verbo Divino, 2015.

BAARDA, T.: "'Fulfilled are the Times'. A neglected varia lectio in Mark 1:15", FN 27(47), 2014, 67-74.

Balz, H. - Schneider, G. - Pulido, J.: Vocabulario Griego del Nuevo Testamento. Edición revisada y ampliada, con nuevo vocabulario español-griego. Salamanca, Sígueme, 2015.

BaÑos BAÑos, J. M.: "Colocaciones verbo-nominales y traducción del griego al latín: el Evangelio de San Mateo", Homenaje a Ignacio Rodríguez Alfageme 61-72.

Bermejo Rubio, F.: "Deconstrucción de los relatos evangélicos de la pasión. Sobre el arraigo de la ficción en la Historia de las religiones", 'Ilu 20, 2015, 37-68.

- "La pretensión regia de Jesús el Galileo. Sobre la historicidad de un motivo en los relatos evangélicos", SHHA 33, 2015, 135-157.

Brown, S. G.: "El Evangelio místico de San Marcos", Realidad, ficción y autenticidad en el mundo antiguo 251-270.

Cañas Reíllo, J. M.: "La traducción de la Septuaginta al español: problemas y soluciones", Studia Angelo Urbano dicata 113-125.

Danove, P.: "Rhetorical Applications of New Testament Verbs of Communication", FN 27(47), 2014, $25-41$.

Fernández Marcos, N. (dir.): Biblia griega Septuaginta IV. Libros proféticos. Madrid, Ediciones Sígueme, 2015.

Ferrández Zaragoza, N.: “El que ama a su padre o a su madre más que a mí, no es digno de mí” (Mt. 10, 37): una contribución al estudio de la relación discipulado-familia en el evangelio de San Mateo, con especial referencia al discurso apostólico de Mt 10", EB 73, 2015, 347-372.

FranchI, R.: "Il volto del Dio longanime: i presupposti veterotestamentari, la lettura paolina", Helmantica 66(195), 2015, 171-186.

Gabati Kibeti, G.: "Narration et christologie en Lc 13, 10-17: la guérison de la femme courbée", $E B$ 73, 2015, 45-56.

García, J. M.: "La aparición de Jesús Resucitado a María Magdalena (Jn 20, 11-18)", EB 73, 20I5, 57-77.

García DíAz, M. M.: "Análisis semántico de los lexemas nominales de visión en el griego del Nuevo Testamento", Fortunatae 25, 2014, 147-155.

García Montero, A.: Temas teológicos del Evangelio de San Juan. III. Cristo, María, la Iglesia. Madrid, Rialp, 2014.

GiL Arbiol, C.: "El fracaso del proyecto de Pablo y su reconstrucción", EB 73, 2015, 373-408. 
Gil Fernández, L.: "A cuento del centenario del texto griego de la Políglota complutense", $C F C G$ 25, 2015, 291-300.

GonZÁlez Luis, J.: “Autenticidad y datación del Epistolario de Séneca y san Pablo”, Fortunatae 25, 2014, 169-181.

Hendriks, W.: "Use of Patristic Evidence in Textual Criticism of the Gospels", FN 27(47), 2014, 42-66.

Hinojo AndRÉs, G.: "Logos - Verbum: ¿Traducción correcta?”, Studia Angelo Urbano dicata 387-398.

Horrell, D.G.: "Fear, Hope, and Doing Good: Wives as a Paradigm of Mission in 1 Peter", EB 73, 2015, 409-430.

Law, T.M.: Cuando Dios habló en griego. La Septuaginta y la formación de la Biblia cristiana. Traducción de F. J. Molina. Salamanca, Sígueme, 2014.

López Montero, R.: "Afinidad literaria en símiles mesopotámicos y bíblicos de temática animal”, $E B$ 73, 2015, 169-190.

Martín Asensio, G.: "Dicho y hecho: las palabras de institución como acto de habla en Marcos 14", EB 73, 2015, 25-43.

Melero Gracia, M.L.: Carta de Santiago. Estella, Verbo Divino, 2015.

Nzosa Muyumbu, P. - Wénin, A.: "Une étude rhétorique de la prière de Mardochée dans le livre grec (LXX) d'Esther (Suppl. C, 1-10)", EB 73, 2015, 7-24.

Pagels, E.: Los evangelios gnósticos. Barcelona, Crítica, 2015.

Pena González, M.A. - Delgado Jara, I. (eds.): A quinientos años de la Políglota: El proyecto humanístico de Cisneros. Fuentes documentales y líneas de investigación. Salamanca, Universidad Pontificia de Salamanca, 2015.

Pereira Delgado, A.: “'Pablo libado': la metáfora de la libación y del sacrificio en Filipenses 2,17”, El alimento de los dioses 193-212.

Pérez Gondar, D.: "Zacarías, hijo de Baraquías (Mt 23,35) locus theologicus a la luz de la literatura judía intertestamentaria", $E B$ 73, 2015, 191-213.

Pérez Millos, S.: Comentario exegético al texto griego del Nuevo Testamento. Colosenses. Barcelona, Clíe, 2015.

Piñero, A.: Guía para entender a Pablo de Tarso. Una interpretación del pensamiento paulino. 2015.

Piñero Sáenz, A.: "Otra manera de entender la Segunda carta a los corintios", Homenaje a Ignacio Rodríguez Alfageme 677-692.

PItTs, A.: "Tarsus or Jerusalem? A Syntactic Argument for Tarsus as the City of Paul's Youth in Acts 22:3", FN 27(47), 2014, 75-82.

Rius-Camps, J. - Read-Heimeerdinger, J.: "The Variant Readings of the Western Text of the Acts of the Apostles (XXVI) (Acts 20:1-21:14)”, FN 27(47), 2014, 111-151.

Rodríguez Carmona, A.: Evangelio según san Lucas. Madrid, Biblioteca de Autores Cristianos, 2014.

- Hechos de los Apóstoles. Madrid, Biblioteca de Autores Cristianos, 2015.

Rodríguez-Pantoja Márquez, M.: "Traducir los Evangelios", Studia Angelo Urbano dicata 581-596.

Rosell Nebreda, S.: "El papel de la eucaristía en el Nuevo Testamento y su recepción e interpretación en la tradición reformada", El alimento de los dioses 229-252.

Smit, P. B. - Renssen, T.: "The passivum divinum: The Rise and Future Fall of an Imaginary Linguistic Phenomenon", FN 27(47), 2014, 3-24.

Spottorno, M. V.: "Los Bíblicos de Montserrat", La mano del escriba 76-90.

Tekleberhan, M.: "The reception and appropriation of 1 Corinthians 7:1-9 in selected Ethiopic texts", CCO 12, 2015, 235-248.

Trebolle Barrera, J.: "Significado y actualidad de una Biblia políglota: libros bíblicos transmitidos en varias ediciones", $E B$ 73, 2015, 79-108.

URBÁN FERNÁNDEZ, Á.: "La edición y estudio filológico de un manuscrito inédito bilingüe, greco-árabe, del Evangelio de Lucas del siglo XI (BnF, suppl. gr. 911, año 1043): problemática de la edición de textos bíblicos", Europa Renascens 579-606. 
VAnhoye, A.: Carta a los Hebreos. Madrid, BAC, 2014.

Yoon, D. I.: "Discourse Analysis and the Textual Metafunction: Analyzing the Texture of Galatians 4:12-20", FN 27(47), 2014, 83-110.

\section{Callimachus}

Rodoni, M. A.: “Ártemis y la ciudad en el Himno a Ártemis de Calímaco”, CFCG 25, 2015, 215-222.

Rodríguez Alfageme, M. I.: "Notas al Himno V de Calímaco", CFCG 25, 2015, 193-213.

\section{Cebes}

Marco Aurelio - Teofrasto - Epicteto - Cebes: Obras de los moralistas griegos. Clásicos recuperados. Segunda edición corregida y actualizada por F. Valiente-Méndez. Sevilla, Isla de Siltolá, 2015.

\section{Charito}

Sanz Morales, M.: "La lengua de Caritón de Afrodisias: características morfológicas", CFCG 25, 2015, 39-66.

\section{Chrysostomus, Iohannes}

JuAn CRIsóstomo: La virginidad. Traducción de I. Garzón Bosque. Madrid, Ciudad Nueva, 2014.

\section{Clemens Alexandrinus}

Herrero de JÁuregui, M.: “Aristotechnas”, Homenaje a Ignacio Rodríguez Alfageme 367-378.

\section{Codex Iustinianus}

Bueno Delgado, J.A.: La legislación religiosa en la compilación justinianea. Madrid, Dykinson, 2015.

\section{Colluthus}

Dubois Silva, S.: "Algunas notas sobre el uso del vocabulario poético en Coluto", E barbatulis puellisque 97-112.

\section{Corinna}

RodríGuez Piedrabuena, S.: “Boeotica incerti auctoris?”, Europa Renascens 469-482.

— "Corina y sus conjeturas", E barbatulis puellisque 125-136

\section{Corpus Hermeticum}

Sánchez Pérez, C.: "La recepción del Corpus Hermeticum en Promethea de Alan Moore", E barbatulis puellisque 275-282.

\section{Crates Thebanus}

Fuentes GonzÁlez, P. P.: “La 'reacuñación’ cínica de la familia en Crates de Tebas", Studia Angelo Urbano dicata 201-217.

\section{Demosthenes}

Hernández Muñoz, F. G.: "La cuarta Filípica de Demóstenes", CFCG 25, 2015, 317-340.

- "Nueva edición crítica de la Primera Olintíaca demosténica", Homenaje a Ignacio Rodríguez Alfageme 353-366.

\section{Dictys Cretensis}

Movellán Luis, M.: "Elementos paródicos en la Ephemeris Belli Troiani”, 137-148. 
Movellán Luis, M.: "La crónica troyana de Dictis: la forma en prosa como relato histórico", Ianua Classicorum II 247-253.

\section{Didymus Alexandrinus}

Pajón Leira, I.: "Los comentarios del Génesis y Zacarías de Dídimo el Ciego", La mano del escriba 91-100.

\section{Dio Cassius}

UrRUtia Muñoz, N.G.: Las formas de la memoria en la historiografía griega del siglo III romano. Utilización del recuerdo en Dión Casio y Herodiano. Tesis Doctoral, Universidad Autónoma de Barcelona, 2015. http://www.tesisenred.net/handle/10803/287911

\section{Dio Chrysostomus}

Urbán Fernández, Á.: "El discurso de Dión Crisóstomo, Diógenes o sobre la Virtud (Or. 8)", Humanismo y pervivencia del mundo clásico $V$, vol.I 415-442.

\section{Diodorus Siculus}

Hernández-Tejero Larrea, I.: "Los pueblos asiáticos en Diodoro Sículo", Orientalística en tiempos de crisis 219-232.

\section{Diogenes Sinopensis}

López Cruces, J.L.: “Diógenes, ciudad sin ley”, En Grecia y Roma V177-194.

\section{Dionysius Halicarnassensis}

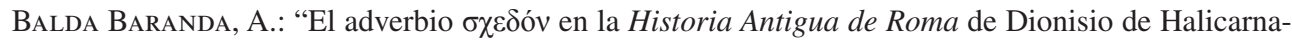
so", E barbatulis puellisque 87-96.

Rodríguez Horrillo, M.Á.: "El proemio a las Antigüedades romanas de Dionisio de Halicarnaso: apuntes para los primeros pasos del clasicismo historiográfico", Ph.Canar.20, 2014, 115-133.

\section{Dioscorides}

Cortés Gabaudan, F. - Ureña Bracero, J.: "Presentación del Dioscórides Interactivo", Ianua Classicorum II 107-113.

DE Hoz Bravo, J.: "Una nota sobre el beleño en la antigüedad", Homenaje a Ignacio Rodríguez Alfageme 161-170.

\section{Ephorus}

CABallero López, J. A.: "De la retórica a la historia: la prosa historiográfica de Éforo", Veleia 32, 2015,17-28.

CAmacho Rojo, J. M.: “Éforo de Cime, primer historiador universal”, En Grecia y Roma V29-47.

\section{Epictetus}

García Bueno, C.: "Una traducción latina anónima de los comentarios de Arriano a Epicteto", Ianua Classicorum III 355-361.

Marco Aurelio - Teofrasto - Epicteto - Cebes: Obras de los moralistas griegos. Clásicos recuperados. Segunda edición corregida y actualizada por F. Valiente-Méndez. Sevilla, Isla de Siltolá, 2015.

\section{Epicurus}

EPICURo: Cartas y sentencias (seguido de la Filosofía de Epicuro de Cicerón). Traducción de F. Ortega. Palma, Olañeta, 2015. 
Molina Sánchez, M.: “Epicuro, a los ojos de Lucrecio”, En Grecia y Roma V241-251.

\section{Euangelium Petri}

Edo, P.M.: El evangelio de Pedro. Edición bilingüe y comentario. Salamanca, Ediciones Sígueme, 2015.

\section{Euripides}

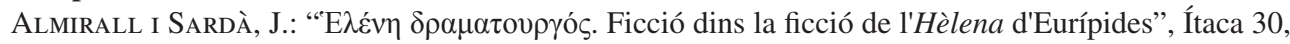
2014, p. 59-75.

Breviatti Álvarez, J.: Bacantes de Eurípides. Felicidad iniciática y furia salvaje en el cortejo femenino de Dioniso. Tesis doctoral. Universidad del País Vasco, 2011; versión en línea 2015. https:// addi.ehu.es/handle/10810/15235

- "El grupo de mujeres de Tebas: caza e imaginería animal en Las Bacantes de Eurípides", Myrtia 30, 2015, 35-60.

Calero Secall, I.: "Las viejas reinas del teatro de Eurípides: imbricación de rasgos femeninos y masculinos", Europa Renascens 63-84.

Cendán Teijeiro, N.: "Andrómaca, de Homero a Eurípides: Un ejemplo de recaracterización euripidea”, Ianua Classicorum II 91-97.

Encinas Reguero, M. C.: "Eurípides, Bacantes 576-641 o la escena del `milagro del palacio”, Ianua Classicorum II 115-122.

EuRíPIDES: Las Bacantes. Traducción, introducción y guía didáctica de R. García Rodero. Oviedo, KRK Ediciones, 2015.

— Las troyanas. Traduccíón de R. Irigoyen Larrea. Madrid, Alianza Editorial, 2015.

- Tragèdies, vol. III: Hipòlit. Andròmaca. Noticies preliminars, text revisat, traducció i notes de M.R. Llabrés. Col-lecció dels Clàssics Grecs i Llatins 408. Barcelona, Fundació Bernat Metge, 2015.

Gómez Seijo, F.: Caracterización de Helena en la tragedia homónima de Eurípides. Tesis doctoral. Universidad de Santiago de Compostela, 2015. https://digitalis.uc.pt/pt-pt/livro/caracterizaci\%C3\%B3n_de_helena_en_la_tragedia_hom\%C3\%B3nima_de_eur\%C3\%ADpides_y_tradici\%C3\%B3n_posterior_del

Guzmán García, H.: "Eurípides en la ópera: Le Sconfitte de Claudio Gay", Ianua Classicorum III 649-656.

Jiménez Justicia, L.: "El prólogo del Cíclope de Eurípides”, Tycho 3, 2015, 25-38.

Jiménez LóPez, M. D.: "Eurípides, Medes", La vida a escena 34-76.

Ledesma Pascal, F.: "La experiencia trágica: historia, política y tragedia en la Atenas del siglo v a.C. (A propósito de Las Troyanas de Eurípides)", Ianua Classicorum II 197-205.

López Férez, J. A.: "Las Fenicias de Eurípides: tragedia, mito, pensamiento, léxico", Fortunatae 25, 2014, 239-259.

López Fonseca, A.: "Las mujeres que perdieron la guerra en la escena española del siglo XX: Hécuba y Las Troyanas de Eurípides", Homenaje a Ignacio Rodríguez Alfageme 441-450.

Martínez Bermejo, M. Ll.: "Comentarios y marginalia al texto de Eurípides en los papiros", Ianua Classicorum II 223-230.

Melone, H. M.: "Dioses y mortales en el Hipólito de Eurípides", FI 26, 2015, 91-103.

Perusino, F.: "I poeti `artefici di inni' in Euripide, Andr. 476", Homenaje a Ignacio Rodríguez Alfageme 659-664.

Pellegrino, M.: "Il personaggio del vecchio pedagogo nello Ione di Euripide", Homenaje a Ignacio Rodríguez Alfageme 621-644.

REVERT SORIANo, R.: Reflexiones en torno al nómos en las tragedias tardías de Eurípides. Tesis doctoral. Universidad de Valencia, 2015. http://roderic.uv.es/handle/10550/43259 
Revert Soriano, R.: "Un personaje secundario en una obra coral: el pedagogo de Fenicias", Tycho 3, 2015, 91-108.

Romero Mariscal, L.: "El texto escénico de Las Troyanas de Eurípides: maquinaria, objetos, vestuario, escenografía y comunicación trágica”, Europa Renascens 495-512.

\section{Galenus}

Boned, P.: "Teorías sobre la reproducción: Consideraciones acerca del contenido y la composición del De Semine de Galeno", Galeno. Lengua, composición literaria, léxico, estilo 57-62.

Boudon-Millot, V.: "De l'art de la citation: Galien lecteur des auteurs antiques", Homenaje a Ignacio Rodríguez Alfageme 97-116.

- "La notion d'aeipatheia dans la pathologie de Galien", Galeno. Lengua, composición literaria, léxico, estilo 191-202.

Cerezo Magán, M.: La salud según Galeno: de acuerdo con su obra Sobre cómo hay que proteger la salud y un epílogo sobre la salud y la enfermedad en la terminología galénica. Lérida, Universidad, 2015.

- "Mitema poético frente aphysis: el mito de los centauros en De usu partium de Galeno", Galeno. Lengua, composición literaria, léxico, estilo 109-128.

Cortés Gabaudan, F.: "Pervivencia actual del vocabulario médico de Galeno", Galeno. Lengua, composición literaria, léxico, estilo 129-178.

Galeno: Arte médica. Introducción, traducción, notas e índices de P. Espinosa Espinosa. Madrid, Ediciones Clásicas, 2015.

- Sobre las facultades de los alimentos. Introducción, traducción, notas e índices de M. J. Zaragoza Gras. Madrid, Ediciones Clásicas, 2015.

- Sobre los pulsos para los principiantes. Sobre la utilidad de los pulsos. Estudios introductorios, traducción, notas e índices de L. M. Pino Campos. Madrid, Ediciones Clásicas, 2015.

García Novo, E.: "Tiempo, descripción y narración en el tratado de Galeno De inaequali intemperie", Galeno. Lengua, composición literaria, léxico, estilo 349-368.

García Ruiz, J. M.: "El estilo en el comentario Sobre la dieta sana de Galeno", Galeno. Lengua, composición literaria, léxico, estilo 345-348.

García Sola, M. C.: "Galeno: la Odontoestomatología. Avance y retroceso", Galeno. Lengua, composición literaria, léxico, estilo 295-314.

Garofalo, I.: "Variazioni dottrinali nell' anatomia di Galeno", Galeno. Lengua, composición literaria, léxico, estilo 239-244.

Guardasole, A.: "Galeno e i tragici greci”, Galeno. Lengua, composición literaria, léxico, estilo 77-92.

IERACI Bio, A. M.: "Astrologia e medicina nella polemica fra Manuele I Comneno e Michele Glica", Galeno. Lengua, composición literaria, léxico, estilo 389-400.

JounnNA, J.: "Histoire du mot $\alpha i \mu \alpha ́ \lambda \omega \psi$ d'Hippocrate à Galien et à la médecine tardive: contribution à l'étude des dérivés en - $\alpha \lambda$ - de la famille de $\alpha \tilde{\mu} \mu \alpha$ et des termes techniques en - $\omega \psi "$, Galeno. Lengua, composición literaria, léxico, estilo 223-238.

Lara Nava, D.: "Estudio formal del tratado Sobre las diferencias de los síntomas", Galeno. Lengua, composición literaria, léxico, estilo 63-76.

Lillo, A.: "Aspectos sintácticos de la lengua de Galeno", Galeno. Lengua, composición literaria, léxico, estilo 11-28.

López Férez, J. A.: "Algunos términos retóricos en Galeno", Galeno. Lengua, composición literaria, léxico, estilo 245-274.

— "El semen femenino en Galeno", Imaginarios científicos 41-84.

López Salvá, M.: "Símiles y metáforas en Galeno", Homenaje a Ignacio Rodríguez Alfageme 451462. 
Pino Campos, L. M.: "Apuntes en torno a la esfigmología galénica: laSinopsis", Galeno. Lengua, composición literaria, léxico, estilo 315-343.

— "La obra jurídica de Solórzano y las citas de Galeno", Homenaje a Ignacio Rodríguez Alfageme 665-676.

Rodríguez Alfageme, I.: "Patología de la voz en Galeno", Galeno. Lengua, composición literaria, léxico, estilo 203-222.

Roselli, A.: "L'ambiguità dei testi scritti: il De captionibus e i commenti ippocratici", Galeno. Lengua, composición literaria, léxico, estilo 45-55.

Rubio Fernaz, S.: "Ironía y burla: el humor ácido de Galeno", Galeno. Lengua, composición literaria, léxico, estilo 369-388.

Santana Henríquez, G.: "Estudio semántico de los compuestos con el prefijo $\delta v \sigma-$ en Galeno, especialmente en el tratado Sobre la composición de los medicamentos según los lugares", Galeno. Lengua, composición literaria, léxico, estilo 275-294.

SKoda, F.: "La reflexión de Galeno sobre el léxico griego y el interés que ofrece a la linguística moderna”, Galeno. Lengua, composición literaria, léxico, estilo 179-190.

Tieleman, T.: "Galen, De placitis books IV and V: questions, options and authorities", Galeno. Lengua, composición literaria, léxico, estilo 93-108.

Vela Tejada, J.: "Koiné y aticismo: pautas de análisis lingüístico en Galeno, De antidotis", Galeno. Lengua, composición literaria, léxico, estilo 29-44.

\section{Gorgias}

Fornieles SÁnchez, R.: “¿Quién, qué, cuándo, dónde y por qué? en el Defensa de Palamedes: el paradigma Gorgias”, Ianua Classicorum II 131-138.

\section{Hanno geographus}

Mederos Matrtín, A.: "La exploración del litoral atlántico norteafricano según el periplo de Hannón de Cartago", Gerión 33, 2015, 15-45.

\section{Heliodorus}

FERnÁNDEZ GaRrido, M.R.: "Etiópicas de Heliodoro y los progymnásmata: la écfrasis", Ianua Classicorum II 123-130.

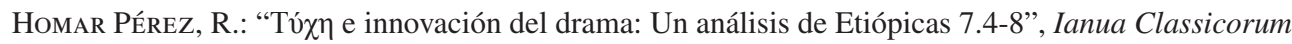
II 189-195.

Pedrero SAncho, R.: “Ópera y novela griega: las Etiópicas de Heliodoro”, Ianua Classicorum III 691-697.

Pomer Monferrer, J. J.: "Les metamorfosis de Teàgenes i Cariclea i el bestiari de les Etiòpiques", Bestiaris i metamorfosis 147-164.

\section{Heraclitus allegorista}

RAMón García, D.: "La tradición manuscrita de las Quaestiones Homericae de Heráclito", Ianua Classicorum II 801-806.

\section{Heraclitus paradoxographus}

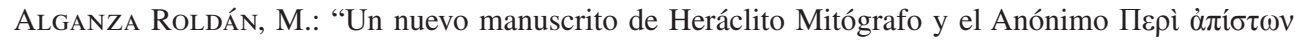
(Movì 'I

\section{Heraclitus philosophus}

Heráclito: Fragmentos. Edición bilingüe. Introducción, traducción, comentarios y notas de A. Medina González y G. Fernández Pérez. Madrid, Encuentro, 2015. 
Genovés Company, R.: "Los fragmentos DK B 3 y B 94 de Heráclito en la columna IV del Papiro de Derveni”, Ianua Classicorum I 255-262.

\section{Hermogenes rhetor}

Pérez Custodio, M.V.: "La recepción de los ejercicios retóricos del Pseudo-Hermógenes en la España del XVI", Humanismo y pervivencia del mundo clásico V, vol.III 1351-1364.

\section{Herodianus historicus}

Urrutia Muñoz, N. G.: Las formas de la memoria en la historiografía griega del siglo III romano. Utilización del recuerdo en Dión Casio y Herodiano. Tesis Doctoral, Universidad Autónoma de Barcelona, 2015. http://www.tesisenred.net/handle/10803/287911

\section{Herodotus}

Bentein, K.: "Aspectual choice with uerba dicendi in Herodotus' Histories", Emerita 83, 2015, 221245.

Heródoto: Historia. Libro III. Talía. Edición blingüe de J.M. Floristán Imízcoz. Madrid, Dykinson, 2015.

Lillo Alcaraz, A.: "Sobre las construcciones finales de Hdt. 1.110.3 y 2.93.4", Homenaje a Ignacio Rodríguez Alfageme 417-428.

Méndez Dosuna, J.: "El enchytrismós de niños expósitos en la antigua Grecia: ¿realidad o ficción?”, Homenaje a Ignacio Rodríguez Alfageme 543-554.

Penadés Chust, A.: Tras las huellas de Heródoto. Córdoba, Almuzara, 2015.

Rodríguez Horrillo, M. Á.: "Reminiscencias herodoteas y elaboración literaria en las Historias de Quinto Curcio Rufo", Myrtia 30, 2015, 119-144.

SÁnChez MaÑas, C.: "Bèsties als oracles herodoteus", Bestiaris i metamorfosis 207-219.

Sierra MARTín, C.: "El oro de las hormigas: paradoxografía y geografía en el lógos indio de Heródoto (Hdt. III. 98-106)", Lucentum 34, 2015, 173-182.

\section{Hesiodus}

GonZÁlez SuÁrez, M.: "Los compuestos de Hesíodo", Habis 46, 2015, 19-33.

Hesíodo: Teogonía. Edición y traducción de E. Suárez de la Torre. Madrid, Dykinson, 20 I4.

Martínez Díez, A.: "Hesíodo. Recepción histórica y literaria en España (siglos XIII-XIX)", Tempus 36, 2014, 7-50.

PÉrez Asensio, J.: "Tradició, traducció i interpretació en el mite hesiòdic de Pandora i la caixa", SPhV 17, 2015, 217-234.

Santamaría Álvarez, M.A.: "El ascenso de Zeus al poder en la Teogonía de Hesíodo y en el poema órfico del papiro de Derveni”, Ianua Classicorum III 63-70.

Santana Henríquez, G.: "Naturaleza y paisaje en el escudo de Heracles (Hes. Sc. 141-319)", Ianua Classicorum II 279-285.

SuÁrez de la Torre, E.: "Las mentiras de las musas y de los poetas (sobre Hes., Th. 26-28)", Studia Classica Caesaraugustana 263-297.

Hierocles facetiarum scriptor

GonZÁlez SuÁrez, M.: "Chistes de maestros: la actividad docente en Philógelos", Ianua Classicorum II 179-187.

\section{Hippocrates et Corpus Hippocraticum}

ÁNGEL y EsPINós, J.: "En torno a un posible hápax sintáctico en el tratado hipocrático Sobre las vírgenes (Littré 8, 466, 8)", Homenaje a Ignacio Rodríguez Alfageme 43-50. 
EsPinosa EsPinosa, P.: "Algunos adjetivos en $-\omega \delta \eta \varsigma$ del $\mathrm{CH}$ no incluidos como tales en el TLG, pero recogidos en fuentes posteriores", Homenaje a Ignacio Rodríguez Alfageme 171-186.

Esteban SAntos, A.: "Los infinitivos en las historias clínicas de las Epidemias", Homenaje a Ignacio Rodríguez Alfageme 187-204.

Gallego Pérez, M. T.: Vida y muerte en el Corpus Hippocraticum. Madrid, Ediciones Clásicas, 2015.

GonZÁlez Manjarrés, M. Á.: "Un testimonio de humanismo médico: las epístolas nuncupatorias de Jano Cornario a sus traducciones latinas de Hipócrates y Pablo de Egina”, Ianua Classicorum III 371-378.

Jounnna, J.: "Histoire du mot $\alpha i \mu \alpha ́ \lambda \omega \psi$ d'Hippocrate à Galien et à la médecine tardive: contribution à l'étude des dérivés en - $\alpha \lambda$ - de la famille de $\alpha \tilde{\mu} \mu \alpha$ et des termes techniques en - $\omega \psi$ ". Galeno. Lengua, composición literaria, léxico, estilo 223-238.

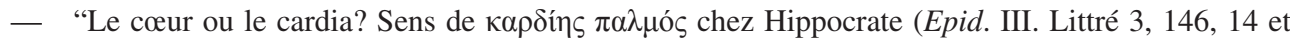
Humeurs, Littré 5, 490,7)", Homenaje a Ignacio Rodríguez. Alfageme 391-404.

\section{Homerus}

AleXander, C.: La guerra que mató a Aquiles. La verdadera historia de la Ilíada. Traducción de J.M. Álvarez-Flórez. Barcelona, Acantilado, 2015.

Brajnovic, L.: Grandes de la literatura (Homero, Dante, Shakespeare), Madrid, Ediciones Rialp, 2015.

Cendán Teijeiro, N.: "Andrómaca, de Homero a Eurípides: Un ejemplo de recaracterización euripidea", Ianua Classicorum II 91-97.

Cline, E. H.: La guerra de Troya. Madrid, Alianza, 2014.

Cristóbal, V.: "Los hombres y las hojas: de Homero a Machado", Myrtia 30, 2015, 285-289.

FonseCA, R. C.: "Heróis animalizados e animais heroificados: Homero entre a tradição épica e o ciclo das antigas epopeias animalescas", Bestiaris i metamorfosis 3-22.

ForNIELES SÁNCHEZ, R.: "La transmisión de noticias en Homero y la tragedia", E barbatulis puellisque 113-124.

Freely, J.: El mundo de Homero. Una guía de viaje por la Ilíada y la Odisea. Barcelona, Crítica, 2015.

Gasent, A.: "Les metamorfosis de Circe: genitiu objectiu o subjectiu?", Bestiaris i metamorfosis 23-36.

GonZÁlez VAquerizo, H.: "El poeta es un fingidor y los cretenses no dejan de mentir: de las mentiras del Ulises homérico a la Odisea de Nikos Kazantzakis", Ianua Classicorum III 621-631.

Homero: Ilíada. Versión de F. Gutiérrez. Barcelona, Penguin, 2015.

- Odisea. Versión de F. Gutiérrez. Barcelona, Penguin, 2015.

- Odisea. Introducción, selección y notas de A. Martínez Díez. Madrid, Ediciones Clásicas, 2015.

- Odisea. Las aventuras de Ulises contadas por Charles Lamb. Madrid, Gadir, 2015

La Ulixea de Homero, traducida de griego en lengua castellana por el secretario Gonzalo Pérez. Primera traducción de la Odisea al castellano, por Gonzálo Pérez, secretario de Felipe II en endecasílabos sin rima. 2 vols. Málaga, Universidad, 2015.

López Melero, R.: "Fuerza y violencia en el marco de la épica griega", Nómos ágraphos - Nómos éngraphos81-108.

Macía Aparicio, L. M.: "La primera edición de la Ilíada publicada en España", Ianua Classicorum II 761-764.

Mendoza Tuñón, J. M.: "Muerte e inmortalidad: Homero y las creencias indoeuropeas", Homenaje a Ignacio Rodríguez Alfageme 555-566.

Nodar Domínguez, A.: "Los papiros homéricos", La mano del escriba 53-68.

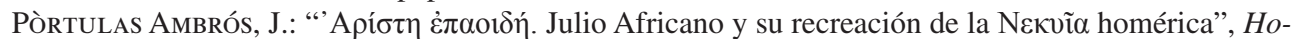
menaje a Ignacio Rodríguez, Alfageme 705-716.

Reboreda Morillo, S.: "El protagonismo de las madres homéricas y su papel como educadoras", Género y enseñanza de la historia 163-185. 
Santana Henríquez, G.: "Viandas y manjares en Homero", Fueron felices y comieron perdices 1134.

Signes Codoñer, J.: "Homero en tierras del Islam en el siglo IX: Una presencia quizás no tan episódica", 1005-1020.

VerzinA, P.: "Zeus e il vantaggio troiano: tracce di elaborazioni della tradizione nell'Iliade", Emerita $83,2015,195-219$.

\section{Hymni Homerici}

Torné TeIXIdó, R.: "La presència d'animals en els Himnes Homèrics, entre el símbol i el relat", Bestiaris i metamorfosis 273-282.

\section{Iamblichus philosophus}

IÀMBLIC: La vida pitagórica. Introducció, text grec revisat, traducció i notes de M. Jufresa i A. Xurigué. Col-lecció dels Clàssics Grecs i Llatins 407. Barcelona, Fundació Bernat Metge, 2015.

\section{Iosephus}

Flavio Josefo: Autobiografía. Sobre la Antigüedad de los judíos. Edición de M. ${ }^{a}$ V. Spottorno Díaz-Caro y J. R. Busto Saiz. Madrid, Alianza, 2015.

\section{Iulianus imperator}

García Ruiz, M. P.: "Una lectura conjunta del primer Encomio a Constancio y el Encomio a Eusebia de Juliano", EC 19, 2015, 155-173.

Moreno Pampliega, J.: "Ética y religión en los escritos del emperador Juliano", Ianua Classicorum I 277-284.

Muñoz García de Iturrospe, M. T.: "El tirano filósofo como canis rabidus: el emperador Juliano desde Jerónimo", Humanismo y pervivencia del mundo clásico V, vol.II 607-622.

Quiroga Puertas, A. J.: "El emperador Juliano”, En Grecia y Roma V325-340.

Redondo Moyano, E.: "Gore Vidal y su recreación novelesca de Juliano el Apóstata”, Humanismo y pervivencia del mundo clásico $V$, vol.V 2659-2671.

\section{Libanius}

García Soler, M. J.: "La imagen cómica del filósofo en la declamación XXIX de Libanio", Homenaje a Ignacio Rodríguez Alfageme 295-304.

Pérez Galicia, G.: "Más amistoso que un banquete": una rica miniatura literaria de Libanio (Lib., Ep. 996F)", Minerva 28, 2015, 221-239.

\section{Lucianus}

VAN DıJK, G. J.: "Luciano y la fábula”, Ianua Classicorum II 295-302.

\section{Lydus, Iohannes Laurentius}

RodRíGuez LóPEZ, R.: "Juan Lido", En Grecia y Roma V379-395.

\section{Lyrica adespota}

Amado Rodríguez, M. T.: “Álvaro Cunqueiro y la ‘Canción rodia de la golondrina”, Humanismo y pervivencia del mundo clásico $V$, vol.V 2369-2382.

\section{Lysias}

García Domingo, E.: “Una multa sagrada (Lisias 9)”, EClás.147, 2015, 31-52. 


\section{Magica}

Ballesteros, B.: "Las fórmulas de tintas mágicas en los PGM", Los papiros mágicos griegos 45-56.

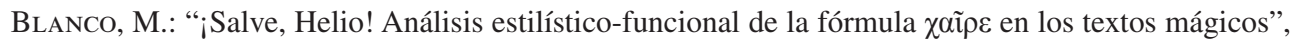
Los papiros mágicos griegos 111-132.

Chronopoulou, E.: "El oficio peligroso del mago", Los papiros mágicos griegos 3-30.

García Molinos, A.: "La cólera de Crono en PGM IV 3086-3124”, Ianua Classicorum I 247-254.

— "Sobre los recursos para persuadir al lector en los papiros griegos mágicos", Los papiros mágicos griegos 31-44.

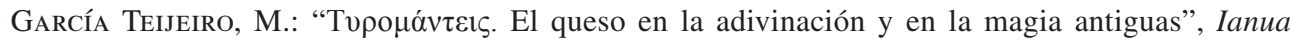
Classicorum II 665-671.

MastrocinQue, A.: "Acanto e spade nella magia amorosa", $M H N H$ 14, 2014, 25-38.

Molinos Tejada, M. T. - García Teijeiro, M.: "Una acusación de magia en el segundo concilio de Éfeso del 449", Los papiros mágicos griegos 173-190.

NisSan, E.: "Animals calling out to Heaven: In support of the hypothesis of an Alexandrine Egyptian connection to the animals praising Heaven in Pereq Shirah (A chapter of hymns): Some evidence from Egypt's Greek magical papyri”, $M H N H$ 14, 2014, 167-196.

Nodar, A. - Torallas, S.: "Paleography of magical handbooks: an attempt?", Los papiros mágicos griegos 59-66.

Perea Yébenes, S.: "Los 'dátiles de Nicolás' (de Damasco) y la tinta mágica en los PGM y la literatura rabínica”, Studia Angelo Urbano dicata 537-552.

Porres Caballero, S.: "Dioniso, el joven no joven (IO PMG 744)", Ianua Classicorum II 263-269.

SCAPINI, M.: "Whipping in ritual and magic practice: a case of convergence", Los papiros mágicos griegos 93-110.

SuÁreZ de LA Torre, E.: "Observaciones sobre PGMXXXVI (P. Bibl. Univ. Oslo inv. n 1)", Los papiros mágicos griegos 67-90.

— "Un anticonceptivo único en el mundo", Homenaje a Ignacio Rodríguez Alfageme 765-780.

ZAGO, M.: "¿Inquietudes filosóficas en los papiros mágicos? Una comparación con Porfirio de Tiro", Los papiros mágicos griegos 157-172.

Zografou, A.: "Hékate des rúes dans les papyrus magiques.Des enfers aux mystéres: P. Mich. III, 154 =PGM LXX, 4-19”, Los papiros mágicos griegos 135-156.

\section{Marcus Aurelius Antoninus}

Campos Daroca, J.: "Marco Aurelio en persona", En Grecia y Roma V 49-61.

Marco Aurelio: Meditaciones. Trad. de A. Guzmán Guerra. Madrid, Alianza, 2014.

Marco Aurelio - Teofrasto - Epicteto - Cebes: Obras de los moralistas griegos. Clásicos recuperados. Segunda edición corregida y actualizada por F. Valiente-Méndez. Sevilla, Isla de Siltolá, 2015.

Maximus Tyrius

Martínez Hernández, M.: "La erótica de Sócrates en Máximo de Tiro", Ianua Classicorum II 231-237.

\section{Menander}

Boned Colera, P.: “Los diminutivos en Menandro”, Ianua Classicorum I 477-483.

\section{Nicolaus Damascenus}

Perea Yébenes, S.: "Los `dátiles de Nicolás' (de Damasco) y la tinta mágica en los PGM y la literatura rabínica", Studia Angelo Urbano dicata 537-552.

- "Los inicios de César (Octavio) como jefe militar: el año 44, de Apolonia a Roma, según la obra

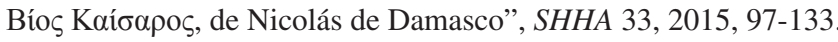




\section{Nicomachus Gerasenus}

GARrido Domené, F.: “Lo que vibra es el yunque”, Ianua Classicorum II 673-680.

\section{Nonnus}

García-Gasco Villarrubia, R.: "El toro en las Dionisíacas de Nono: metamorfosis divina y símbolo profético", Ianua Classicorum II 147-154.

\section{Origenes}

Crouzel, H.: Orígenes. Un teólogo controvertido. Madrid, Biblioteca de Autores Cristianos, 2015.

Orígenes: Homilías sobre el Evangelio de Lucas. Traducción de A. López Kindler. Madrid, Ciudad Nueva, 2014.

- Sobre los principios. Edición bilingüe preparada por S. Fernández. Madrid, Ciudad Nueva, 2015.

\section{Orphica}

Aparicio Villalonga, C.: "La concepción del sabio en el estoicismo y su similitud con el autor del papiro de Derveni", Ianua Classicorum I 213-222.

Bernabé Pajares, A.: "Ambigüedad espacial en Plutarco fr. 178 Sandbach y en el Papiro de Derveni“", Homenaje a Ignacio Rodríguez Alfageme 83-96.

— “Apuntes sobre la col. IV del papiro de Derveni”, Ianua Classicorum III 27-34.

CAsadesús Bordoy, F.: "Algunas consideraciones sobre la cosmovisión ética del anónimo autor del Papiro de Derveni”, Ianua Classicorum I 239-246.

Genovés Company, R.: "Los fragmentos DK B 3 y B 94 de Heráclito en la columna IV del Papiro de Derveni", Ianua Classicorum I 255-262.

Jiménez SAn Cristóbal, A. I.: "El PSI 850 (OF 310): nuevas propuestas de lectura", Ianua Classicorum III 53-61.

MaRtín HeRnández, R.: La ciencia de Orfeo. Lapidarios y escritos sobre astrología y medicina. Madrid, Antígona, 2015.

Megino Rodríguez, C.: "El autor del Papiro de Derveni a la luz de la concepción estoica del sabio como experto en artes adivinatorias", Ianua Classicorum I 269-276.

Santamaría Álvarez, M. A.: "El ascenso de Zeus al poder en la Teogonía de Hesíodo y en el poema órfico del papiro de Derveni”, Ianua Classicorum III 63-70.

\section{Parmenides}

Cornford, F.M.: Platón y Parménides. Traducción de F. Giménez García. Madrid, Machado Libros, 2015.

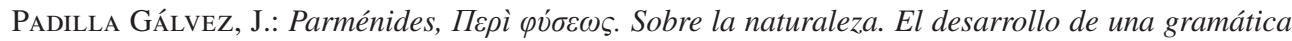
metafísica. Edición, traducción y comentario filosófico. Madrid, Ápeiron Ediciones, 2015.

Solana Dueso, J.: Parménides. El canto del filósofo. Barcelona, Edhasa, 2013.

\section{Parthenius}

Gallé Cejudo, R. J.: "Partenio de Nicea, el motivo de Tarpeya y la Fundación de Lesbos atribuida a Apolonio de Rodas", Studia Angelo Urbano dicata 219-231.

\section{Paulus Aegineta}

GonZÁlez Manjarrés, M. Á.: "Un testimonio de humanismo médico: las epístolas nuncupatorias de Jano Cornario a sus traducciones latinas de Hipócrates y Pablo de Egina", Ianua Classicorum III 371-378. 


\section{Philo Iudaeus}

PÉrez, L.: "Concepciones sobre la reproducción sexual en Filón de Alejandría y sus antecedentes científicos griegos", $C F C G$ 25, 2015, 273-289.

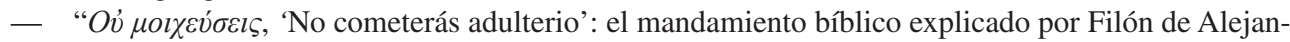
dría”, Emerita 83, 2015, 87-109.

\section{Philostratus}

Gallé Cejudo, R.J.: "La perversión progimnasmática en las Epístolas de Filóstrato", Europa Renascens 139-148.

\section{Philoxenus Leucadius}

Amado Rodríguez, M.T.: "Influencia homérica en el Banquete de Filóxeno", Emerita 83, 2015, 47-62.

\section{Phocylides}

Herrero de Jáuregui, M.: "Universalismo ético e identidad religiosa en las sentencias de pseudoFocílides", Bandue 8, 2014-2015, 83-95.

\section{Physiologus Graecus}

Narro, Á.: "Les versions françaises médiévales du Physiologos et la description de la licorne", Bestiaris i metamorfosis 109-120.

\section{Pindarus}

Pitotto, E.: "Medicina e utopia. Il caso della Pitica III cone indizio di un intreccio antico", Imaginarios científicos 19-32.

\section{Platón}

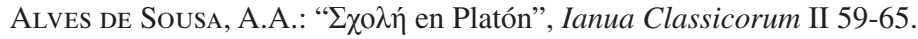

Amorós, P.: La tradición en Platón. Prólogo de L. Brisson. Madrid, Ediciones Irreverentes, 2015.

Bordoy Fernández, A.: “¿Por qué Proclo omite el comentario de Pl. Ti. 47e-48a? Influencias órficas en los comentarios de Proclo a Timeo y República”, Ianua Classicorum I 231-238.

Brann, E.: La música de la República. Ensayos sobre las conversaciones de Sócrates y los escritos de Platón. Edición de A. Lastra. Valencia, Universidad, 2015.

Cano Cuenca, J.: "Una educación política. Apuntes sobre la función de la geometría en el Teeteto y La República", Imaginarios científicos 85-104.

Coelho Sarro, E.: "El canon platónico de jueces infernales “, Ianua Classicorum II 99-106.

Cornford, F. M.: Platón y Parménides. Traducción de F. Giménez García. Madrid, Machado Libros, 2015.

Escudero Muñoz, M.: Derechos civiles de la mujer en la filosofía de Platón. Madrid, Líneas de Distribución Logística del Papel, 2015.

Fernández Figares, M. D.: Los amigos de Platón. Granada, Dauro, 2015.

FERRARI, A.: I miti dell'aldilà. Analisi strutturale e interpretazione per una ridefinizione del ruolo del racconto escatológico all'interno del corpus platónico. Tesis doctoral, Universidad de Barcelona, 2015. http://www.tdx.cat/handle/10803/364767

García-Baró López, M.: "El discurso de Fedro en el simposio que se celebró en honor de Agatón", Sócrates. La muerte del hombre más justo 85-100.

García Novo, E.: "Los siete velos que envuelven el discurso sobre el amor en El Banquete de Platón", Homenaje a Ignacio Rodríguez Alfageme 277-284.

GonZález Arenas, M. I.: "La construcción paródica del mito de la caverna en el s. XX: de Platón a Virgilio Piñera”, Ianua Classicorum III 613-620. 
Herrero de Jáuregui, M.: “Aristotechnas", Homenaje a Ignacio Rodríguez Alfageme 367-378.

Maquieira, H.: "Caracterización funcional del adverbio ě $\tau$ en los Oradores y Platón", Myrtia 30, 2015, 185-206.

MerkL, H.: "El Quijote Cervantino como respuesta al Eutidemo de Platón. Sobre mentira y contradicción”, Humanismo y pervivencia del mundo clásico V, vol.V 2607-2619.

Montes Cala, J. G. -Fernández Montañez, M. P.: "Luis Cernuda, lector de Platón en Glasgow. Trazas del Fedro en la primera edición de Ocnos", Homenaje a Ignacio Rodríguez Alfageme 581-598.

Morales Caturla, T.: El Critias de Platón. Un mundo mítico para una irrealizable épica del bien. Tesis doctoral, Universidad Nacional de Educación a Distancia, 2015. http://e-spacio.uned.es/fez/ view/tesisuned:Filosofia-Tmorales

Ortiz de Landézuri, M. C.: Purificar la mirada. La dimensión ética del saber en Platón. Madrid, Dykinson, 2015.

PLATó: Diàlegs vol. XX: Les lleis (llibres IV-VI). Introducció, revisió del text grec, traducció i notes de M. Camps. Col-lecció dels Clàssics Grecs i Llatins 410. Barcelona, Fundació Bernat Metge, 2015.

Platón: Obras completas de Platón. Vols. 5-11. Traducción de P. de Azcárate Diz. Segunda edición corregida y actualizada por A. Pérez Vega. Sevilla, Ediciones de la Isla de Siltolá, 2015.

- Parménides. Traducción de G. R. de Echandía. Madrid, Alianza, 2015.

RIJKSBARON, A.: "On the syntax and pragmatics of inquit formulae in Plato's narrated dialogues", Ianua Classicorum I 397-410.

Taylor, A. E.: Platón. Traducción de C. García Trevijano. Madrid, Tecnos, 2014.

Verano Liaño, R.: La reformulación discursiva en griego antiguo. Un estudio sobre la República de Platón. Tesis doctoral, Universidad de Sevilla, 2015. https://idus.us.es/xmlui/handle/11441/32835

Verano Liaño, R.: "El habla de Céfalo: algunos rasgos lingüísticos de la caracterización dramática de Platón, República I", E barbatulis puellisque 75-86.

\section{Plutarchus et Pseudo Plutarchus}

Bernabé Pajares, A.: "Ambigüedad espacial en Plutarco fr. 178 Sandbach y en el Papiro de Derveni", Homenaje a Ignacio Rodríguez Alfageme 83-96.

Blasco Torres, A. I.: "La noción egipcia de maat en el De Iside et Osiride de Plutarco", Ianua Classicorum II 83-89.

Herrero de Jáuregui, M.: “Aristotechnas", Homenaje a Ignacio Rodríguez Alfageme 367-378.

IвÁÑEz Chacón, Á.: "Los Parallela Minora en la tardición escoliástica”, E barbatulis puellisque 149-162.

Lesage Gárriga, L.: "Algunas consideraciones sobre la tradición: textual del tratado De Facie de Plutarco", Europa Renascens 201-210.

NARDELLI, J.F.: "Plutarque, de Iside et Osiride, chapitres 1-11: Un commentaire", EC 19, 2015, 29-130.

Pérez-Jiménez, A.: "Los Campos Elíseos: espacios reales e imaginarios de la superficie celeste de la Luna (De facie 944C-945B)", Homenaje a Ignacio Rodríguez Alfageme 645-658.

Pizarro Herrmann, A.: "Eĩ̇o e e ióź en De natura hominis", Homenaje a Ignacio Rodríguez Alfageme 693-704.

Rodríguez García, F.: "Las referencias a Pitágoras en el De Homero 2 de Ps. Plutarco", Habis 46, 2015, 281-297.

Roskam, G.: "An Exegetical Note on Plutarch, Isis and Osiris 351E”, Emerita 83, 2015, 157-164.

Santana Henríquez, G. (ed.): Plutarco y las artes. XI Simposio Internacional de la Sociedad Española de Plutarquistas. Madrid, Ediciones Clásicas, 2013.

SAPERE, A.: "Sentidos y usos del mito en la obra biográfica de Plutarco", Myrtia 30, 2015, 77-98.

\section{Polemo sophista}

Gómez, P.: "Las manos de Maratón: de la narración histórica a la declamación sofística", Ianua Classicorum II 155-162. 


\section{Polybius}

AKA, A. M.: "La rumeur dans le monde grec à travers le discours de Polybe", SHHA 33, 2015, 39-67.

Kalospyros, N. A. E.: "Is there any Mediterranean Utopia? Towards the disputed aspects of Polybius' universal historiography”, Imaginarios científicos 209-222.

\section{Porphyrius Tyrius}

Rodríguez-Noriega Guillén, L.: "Las Cuestiones Homéricas de Porfirio como fuente de la comedia griega", Homenaje a Ignacio Rodríguez, Alfageme 717-728.

\section{Proclus philosophus}

Bordoy Fernández, A.: “¿Por qué Proclo omite el comentario de Pl. Ti. 47e-48a? Influencias órficas en los comentarios de Proclo a Timeo y República”, Ianua Classicorum I 231-238.

\section{Ptolemaeus}

HüBner, W.: "Gender in Ptolemy's Apotelesmatica”, MHNH 14, 2014, 147-166.

\section{Rufus Ephesius}

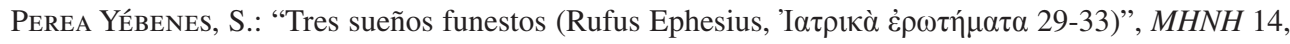
2014, 39-70.

\section{Scylax geographus}

LóPez PARDO, F.: "Rusaddir: de la memoria literaria a la realidad histórica de la expansión feniciopúnica en Occidente", Gerión 33, 2015, 91-103.

\section{Socrates Scholasticus}

Quiroga Puertas, A. J.: "Fidem tene, verba seqventvr. Rhetoric and oratory in the Historia Ecclesiastica of Socrates scholasticus and Sozomen", Veleia 32, 2015,97-108.

\section{Sophocles}

Bañuls Oller, J. V. - Morenilla Talens, C.: “Sófocles, Antígona 1303”, Homenaje a Ignacio Rodríguez Alfageme73-82.

Blázquez Noya, A.: "Las voces de Deyanira en Heroidas IX de Ovidio y Traquinias de Sófocles", Myrtia 30, 2015, 11-33.

Fialho, M. C.: "Ecos de Sete contra Tebas em Rei Édipo de Sófocles", Homenaje a Ignacio Rodríguez. Alfageme 215-224.

Librán Moreno, M.: "Abubillas, cucos y aves rapaces: la autoría de Sófocles, Fr. 581 R. (= Arist., HA 633a 17-28) (Tereo)", Emerita 83, 2015, 247-263.

López Férez, J. A.: "Del Filoctetes de Sófocles a Demasiado tarde para Filoctetes de Alfonso Sastre: huellas de la tragedia sofoclea e innovaciones", Homenaje a Ignacio Rodríguez Alfageme 429-440.

Melero Bellido, A.: "Los fragmentos del Eneo de Sófocles, una parodia satírica", Homenaje a Ignacio Rodríguez Alfageme 529-542.

Pérez LambÁs, F.: "Sobre algunos paralelismos en Áyax y Antígona", Europa Renascens 395-408.

Ramos Aguilar, C.: "El prólogo como diagnóstico, antesala de la enfermedad en Edipo rey", Tycho 3, 2015, 81-90.

Sófocles: Antígona. Introducción, traducción y notas de A. Martínez Díez. Madrid, Ediciones Clásicas, 2015.

Vidal PÉRez, J. L.: "Mendelssohn, intérprete de Sófocles", Humanismo y pervivencia del mundo clásico $V$, vol.V 2347-2361. 


\section{Sozomenos Salaminius}

Quiroga Puertas, A. J.: "Fidem tene, verba seqventvr. Rhetoric and oratory in the Historia Ecclesiastica of Socrates scholasticus and Sozomen", Veleia 32, 2015,97-108.

\section{Strabo}

Estrabón, Geografía. Libros XV-XVII. Traducciones y notas de J. L. García Alonso, M. P. de Hoz García-Bellido y S. Torallas Tovar. Madrid, Gredos, 2015.

- Geografía de Iberia.Traducción de J. Gómez Espelosín. Edición de G. Cruz Andreotti y M. García Quintela. 2. ${ }^{\text {a }}$ edición revisada. Madrid, Alianza Editorial, 2015.

San Vicente González de Aspuru, J. I.: "Reflexiones en torno a Estrabón y las celebraciones ante las puertas de los pueblos del norte de la Península Ibérica”, HAnt.39, 2015, 23-46.

\section{Symeo Stylites}

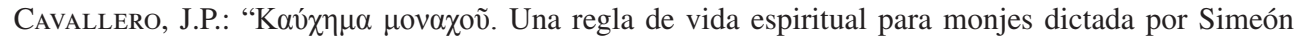
estilita el joven", Helmantica 66(196), 2015, 21-40.

\section{Theodoretus Cyrensis}

ACERBI, S.: "La parrhesia del theios anér en la historia religiosa de Teodoreto de Ciro", EClás.148, 2015, 23-37.

\section{Theophrastus}

Marco Aurelio - Teofrasto - Epicteto - Cebes: Obras de los moralistas griegos. Clásicos recuperados. Segunda edición corregida y actualizada por F. Valiente-Méndez. Sevilla, Isla de Siltolá, 2015.

Teofrasto: Caracteres. Traducción del griego a cargo de E. Fernández Fernández. Madrid, Rialp, 2015.

\section{Thessalus astrologus}

Santamaría Hernández, M.T.: "Testimonios de la traducción latina antigua del De plantis atribuido a Tésalo de Tralles en la versión del Herbario pseudoapuleyano del manuscrito de Wrocław, Biblioteka Uniwersytecka, III F. 19”, Myrtia 30, 2015, 99-117.

\section{Thucydides}

Iglesias-Zoido, J. C.: "De Romilly vs. Kagan: dos Tucídides frente a frente", Talia dixit 10, 2015, 65-73.

- "Sobre la verdadera utilidad de la paraínesis en la historiografía de la época clásica: Tucídides y Jenofonte", Veleia 32, 2015,47-61.

Márquez Cruz, M.: "La Oratio in funere Iohannis Strozzi de Leonardo Bruni y la oración fúnebre de Pericles recogida por Tucídides: ¿sólo inspiración retórica?”, Humanismo y pervivencia del mundo clásico $V$, vol.III 1315-1326.

SANCho Rocher, L.: “Temor, silencio y deliberación: la inhibición de la opinión en Tucídides”, Gerión 33, 2015, 47-66.

Tucídides: Historia de la Guerra del Peloponeso. Barcelona, Juventud, 2015.

\section{Xenopho}

Iglesias Zoido, J. C.: "Sobre la verdadera utilidad de la paraínesis en la historiografía de la época clásica: Tucídides y Jenofonte", Veleia 32, 2015,47-61.

Jenofonte: Helénicas. Edición de J. F. González Castro. Madrid, CSIC, 2016.

\section{Xenopho Ephesius}

Ruiz-Montero, C.: "La autobiografía en la novela griega: Xen. Ephes., V 1,4-11”, Homenaje a Ignacio Rodríguez Alfageme 729-740. 


\section{Zosimus historicus}

Rodríguez Horrillo, M. Á.: "Aspectos formales de la Nueva historia de Zósimo: las narraciones breves”, Ianua Classicorum II 271-278.

\section{HISTORIA DE LA LITERATURA}

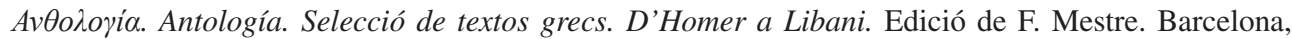
Universidad de Barcelona, 2015.

Bernabé Pajares, A.: "Antología de textos griegos sobre el teatro", La vida a escena 77-96.

Brioso SÁnCHEZ, M.: "Cuestiones metodológicas en torno a la interpretación de las novelas antiguas como Mysterientexte (II)", Habis 46, 2015, 155-175.

Burrow, J.: Historia de las historias. De Heródoto al siglo XX. Barcelona, Crítica, 2014.

Crespo Güemes, E.: "El teatro de Dionisio y la política de Atenas", La vida a escena27-32.

De Martino, F.: "Intonarumori nell'antica Grecia", $S P h V$ 17, 2015, 295-313.

— "Lenticchie e salumi: l'ekphrasis negli storici greci", Veleia 32, 2015, 29-46.

ECheburúa Estévez, I. R.: El griego y su literatura. Historia de la literatura griega clásica. Palma de Mallorca, Novum Publishing, 2015.

- El iambe grec. A l'origen de la sátira. Introducció, traducció i notes de M. R. Llabrés Ripoll. Pollensa, El Gall, 2015.

Fernández CAmacho, P.: "La tumba de Heracles en Gades: una indagación filológico-literaria", Europa Renascens 111-118.

ForNELl MuÑoz, A.: "El aceite bético y su difusión por Occidente a través de los autores clásicos y otras fuentes antiguas", Europa Renascens 119-138.

FoRnieles SÁNCHEZ, R.: La transmisión de noticias en la literatura griega antigua.Tesis doctoral, Universidad Autónoma de Madrid, 2015. https://repositorio.uam.es/handle/10486/666747

— "La transmisión de noticias en Homero y la tragedia", E barbatulis puellisque 113-124.

GaGo SAlDaÑa, M. V.: "El teatro en Grecia", La vida a escena19-25.

Gallé Cejudo, R. J.: "Trazas de materia metamítica en la elegía helenística menor”, Homenaje a Ignacio Rodríguez Alfageme 265-276.

García Romero, F.: De hombres y dioses. Antología de poesía lírica griega antigua (siglos VII-V a. C.). Madrid, Escolar y Mayo, 2015.

- “Sobre algunos 'antiproverbios' en la comedia griega antigua", Homenaje a Ignacio Rodríguez Alfageme 285-294.

García Soler, M. J.: "La figura de Heracles en la comedia y el drama satírico", Ianua Classicorum II 139-145.

- "La figura de Pericles en la comedia antigua", Estudios en honor del profesor Vitalino Valcárcel 329-343.

Gentili, C. - Garelli, G.: Lo trágico. Traducción de E. Jalain. Madrid, Antonio Machado, 2015.

Ginard Puigserver, M.: Bíoi. Tradiciones biogràfiques dels poetes mítics grecs. Tesis Doctoral, Universidad de Barcelona, 2015. https://core.ac.uk/download/pdf/43551482.pdf

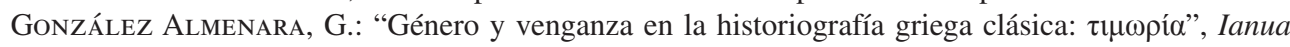
Classicorum II 163-169.

GonZÁlez SuÁrez, M.: Biógrafos griegos menores.Madrid, Ediciones Clásicas, 2015.

GraU, S.: "Las burlas del ascetismo en la biografía de los filósofos griegos antiguos: ¿un reaprovechamiento de materiales cómicos?", Ianua Classicorum II 171-177.

JenKyns, R.: Un paseo por la literatura de Grecia y Roma. Traducción de S. Furió, Barcelona, Crítica, 2015.

Llaguerri Pubill, N.: Nodrizas de tragedia. Mujeres al servicio del teatro griego. Valencia, JPM Ediciones, 2015 . 
López García, A.: "Una revisión de las fuentes históricas que mencionan el Athenaeum de Roma", Habis 46, 2015, 263-281.

LuQue, A.: Aquel vivir del mar. El mar en la poesía griega. Antología. Barcelona, Acantilado, 2015.

LuQue Moreno, J.: "Historia, retórica y poética: para la definición de un antiguo género literario", Europa Renascens 211-246.

López Pardo, F.: “Tingentera, Tingi y el mito de Anteo", Gerión 33, 2015, 105-113.

López Pereira, J. E.: "Del relato literario de viajes al viaje como peregrinación del Mundo Antiguo al Renacimiento", Humanismo y pervivencia del mundo clásico V, vol.II 739-752.

Martínez García, J. - Velázquez, I.: "La investigación moderna ante documentos sospechosos: cuestiones de ficción, falsificación y autenticidad", Realidad, ficción y autenticidad en el mundo antiguo 9-16.

Martínez García, J.: "Problemas en la detección de plagios antiguos y modernos", Realidad, ficción $y$ autenticidad en el mundo antiguo 35-46.

Martínez Hernández, M.: "La importancia de la hetera en la literatura y cultura de la Grecia antigua", Homenaje a Ignacio Rodríguez Alfageme 509-520.

Movellán Luis, M.: "El tópico del manuscrito reencontrado en la encrucijada entre tradición grecorromana y cristianismo en la Antigüedad Tardía", Realidad, ficción y autenticidad en el mundo antiguo 347-356.

MuÑoz García de Iturrospe, M. T.: "Fantasmas y daemones litterati: apariciones de muertos insignes desde la Antigüedad", Fantasmas, aparecidos y muertos sin descanso 117-130.

NARro SÁNCHEZ, Á.: "Aspiraciones historiográficas de la hagiografía griega", Ianua Classicorum III 159-167.

Pascual Barciela, E.: El motivo de la anagnórisis en la tragedia grecolatina y en la española del Renacimiento. Tesis doctoral. Universidad de Burgos, 2015.

Pereña, F.: Repetición e historia: un ensayo sobre lo trágico. Madrid, Síntesis, 2015.

PÉrez Asensio, J.: "El motivo del tesoro en la comedia grecorromana", Ianua Classicorum II 523-529

— "Monstres mitològics en alguns fragments de Comèdia Mitjana i Nova", 135-145.

Piñol Villanueva, A.: "Acceso a la propiedad de bienes raíces por parte de extranjeros en la épica griega arcaica", Ianua Classicorum I 187-193.

QuiJada Sagredo, M.: "Tendencias narrativas en la tragedia griega de finales del s. V a.C.", 27-56.

Quiroga Puertas, A. J.: "Nuevas aportaciones metodológicas a la retórica e historiografía tardo-antiguas" Talia dixit 10, 2015, 75-89.

Redondo Moyano, E.: “Autobiografía griega en época imperial romana”, Estudiosen honor del profesor Vitalino Valcárcel 877-891.

Sánchez Gracia, J.: Hircania en las fuentes clásicas. Análisis de la imagen persa en Grecia y Roma y de la construcción de un tópico literario. Tesis doctoral. Universidad de Zaragoza, 2015. https:// dialnet.unirioja.es/descarga/articulo/5639824.pdf

Wulff Alonso, F.: El peligro infinito. Diosas, mujeres poderosas y héroes en cinco grandes épicas. 2015.

\section{LINGÜÍSTICA GRIEGA. MÉTRICA}

Alonso Aldama, J.: "Los adverbios oṽ $\omega \varsigma$ y Ě $\tau \sigma \iota$ en griego medieval: usos conjuntivos", Ianua Classicorum I 457-465.

Alonso Déniz, A.: "Lo que Tucídides leyó en Olimpia. A propósito de la fuente de Th. 5.47”, Ianua Classicorum I 467-476.

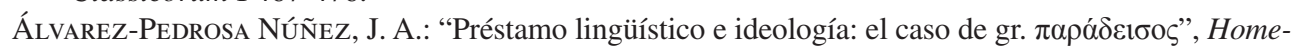
naje a Ignacio Rodríguez Alfageme 29-42. 
ÁNGEL y EsPINós, J.: "En torno a un posible hápax sintáctico en el tratado hipocrático Sobre las vírgenes (Littré 8, 466, 8)", Homenaje a Ignacio Rodríguez Alfageme43-50.

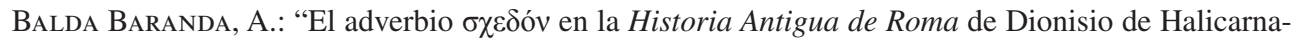
so", E barbatulis puellisque 87-96.

Bentein, K.: "Aspectual choice with uerba dicendi in Herodotus' Histories", Emerita 83, 2015, 221 245.

Boned Colera, P.: "Los diminutivos en Menandro", Ianua Classicorum I 477-483.

Calvo Martínez, J. L.: "El nombre de Orfeo”, Studia Angelo Urbano dicata 101-112.

Cortés Gabaudan, F.: "Sobre la datación de los helenismos anatómicos antiguos", Homenaje a Ignacio Rodríguez Alfageme 127-138.

Crespo Güemes, E.: "Adverbios de foco en Griego Clásico", Studia Classica Caesaraugustana 207234.

— "Foco informativo y foco contrastivo en griego clásico", Homenaje a Ignacio Rodríguez Alfageme 139-150.

- "Los adverbios conjuntivos en griego", Ianua Classicorum I 485-494.

- "Sesión de debate. Lingüística del griego y del latín.- Presentación”, Minerva 28, 2015, 13-14.

De la Villa Polo, J.: "En la mente de los griegos: la lengua como vía de reconstrucción de estructuras mentales", Ianua Classicorum I 413-454.

Esteban Santos, A.: "Los infinitivos en las historias clínicas de las Epidemias", Homenaje a Ignacio Rodríguez Alfageme 187-204.

García Díaz, M. M.: "Análisis semántico de los lexemas nominales de visión en el griego del Nuevo Testamento", Fortunatae 25, 2014, 147-155.

García Romero, F.: "Nombres parlantes en proverbios griegos antiguos", Ianua Classicorum I 495501.

García Trabazo, J. .: "Aproximación al nombre de Ártemis en el contexto del zoomorfismo religioso anatolio", Orientalística en tiempos de crisis 181-190.

GONZÁlez SAAVEDRA, B.: Expresión de la procedencia en lenguas indoeuropeas antiguas: latín, griego e hitita. Tesis Doctoral, Madrid, UCM, 2015. http://eprints.ucm.es/32775/

González Suárez, M.: "Los compuestos de Hesíodo", Habis 46, 2015, 19-33.

Guijarro Ruano, P.: "De las palabras aladas a las letras aladas: el tratamiento de / $w /$ en las incripciones métricas", E barbatulis puellisque 51-62.

- "La expresión de la procedencia en las inscripciones métricas de Olimpia", Ianua Classicorum I 503-512

— "La lengua de las inscripciones métricas laconias anteriores al 400 a.C.", CFCG 25, 2015, 25-37.

Gutiérrez Moreno, J.: "La voz del coloso de Memnón: estudio linguíistico de los términos que la describen", Iапиa Classicorum I 513-522.

JimÉnez Delgado, J. M.: "Eĩ $\tau \alpha$ y है $\pi \varepsilon \imath \tau \alpha$ en los historiadores griegos: de adverbios temporales a marcadores discursivos", Iапиа Classicorum I 523-530.

- "Posición inicial y adverbios conjuntivos en griego antiguo: el caso de غ̌ $\pi \varepsilon \imath \tau$ ", R.S.E.L.44(2), 2014, 39-62.

Konstan, D.: "Cómo decir 'belleza' en griego antiguo", Ianua Classicorum I 263-268.

Labiano Ilundain, M.: "Ancient Greek oĩ $\sigma \theta$ ' ô $\delta \rho \tilde{\alpha} \sigma o v$ : imperatives which do not command", Homenaje a Ignacio Rodríguez Alfageme 405-416.

Lallot, J.: "La completiva: una especie inaprehensible para la gramática antigua", EClás.148, 2015, 5-19.

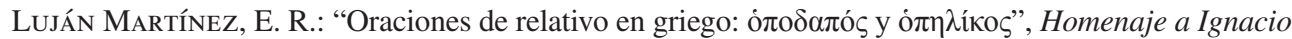
Rodríguez Alfageme 463-476.

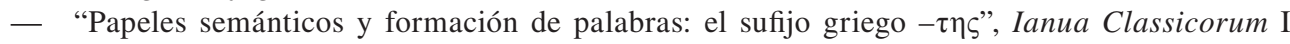
539-548. 
Maquieira, H.: "Caracterización funcional del adverbio ě $\tau$ en los Oradores y Platón", Myrtia 30, 2015, 185-206.

Martínez Vázquez, R.: "El uso conjuntivo y focalizador de ó $\mu$ oí $\omega \varsigma$ en la prosa griega clásica y postclásica", R.S.E.L.44(1), 2014, 65-82.

— "Funciones discursivas de la comparación ecuativa: la correlación $̋ ّ \sigma \varepsilon \rho \ldots$ oṽ $\tau \omega \varsigma "$, Ianua Classicorum I 549-558.

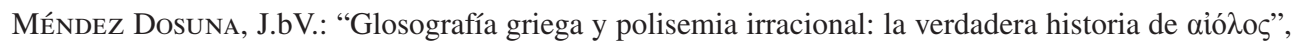
Ianua Classicorum I 357-394.

Monzó Gallo, C.: "Los temas en -u del griego. Un enfoque semántico", Ianua Classicorum I 559-568.

MuÑoz Llamosas, V.: "El origen griego de la expresión alter ego", Ianua Classicorum I 569-578.

NiEto IzQuierdo, E.: "La metátesis de cantidad en el dialecto de Cos: ¿influencia del jonio o desarro1lo propio?", Emerita 83, 2015, 347-357.

- "Koiné y dialectos del griego antiguo durante el s. IV a.C.: un ejemplo peloponesio", Ianua Classicorum I 579-588.

Páez Martínez, M.: "Descripción del uso y evolución de la partícula $\pi \lambda \eta ́ v$ en griego postclásico", Helmantica 66(195), 2015, 93-131.

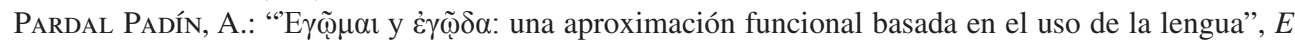
barbatulis puellisque 63-74.

— "La proclisis de los pronombres personales átonos en el drama ático clásico", Ianua Classicorum I 589-598.

QuiJada SAGRedo, M.: “Tendencias narrativas en la tragedia griega de finales del s. V a.C.”, 27-56.

"Koiné y dialectos del griego antiguo durante el s. IV a.C.: un ejemplo peloponesio", Ianua Classicorum I 579-588.

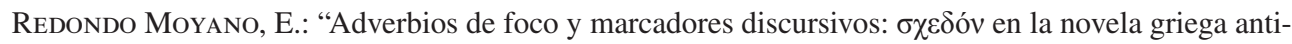
gua”, Minerva 28, 2015, 163-183.

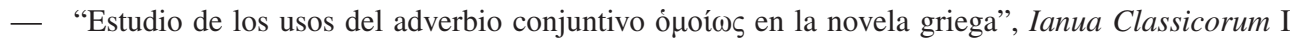
599-608.

Redondo Reyes, P.: "Sobre la letra $b$ en el alfabeto griego utilizado en Bactria", $C F C G$ 25, 2015, 67-83.

RiJKSBARON, A.: "On the syntax and pragmatics of inquit formulae in Plato's narrated dialogues", Ianua Classicorum I 397-410.

Rodríguez Somolinos, H.: El valor de repetición/continuidad en غ̇đl- preverbio", Europa Renascens 483-494.

— "Sobre la preposición غ̇đí en el Diccionario Griego-Español", Ianua Classicorum I 609-615.

Ruiz AbAd, C.: "Distribución de - $\tau \rho o v,-\theta \rho o v,-\tau \rho \bar{\alpha},-\theta \rho \bar{\alpha}$ en griego antiguo", Minerva 28, 2015, 85-105.

Ruiz YamuZA, E.: "El adverbio vṽv como marcador discursivo", Ianua Classicorum I 617-626.

— "Lingüística del griego: una visión general", Minerva 28, 2015, 15-51.

— "Los editores de Sófocles y el adverbio võv", Studia Angelo Urbano dicata 597-611.

— "Periferias derecha e izquierda en griego antiguo", Europa Renascens 513-552.

Schmitz, Ph. C.: "Greek Words in Phoenician and Punic: Recently identified Examples", AuOr 32.1, 2014, 123-141.

VERANo Liaño, R.: La reformulación discursiva en griego antiguo. Un estudio sobre la República de Platón. Tesis doctoral, Universidad de Sevilla, 2015. https://idus.us.es/xmlui/handle/11441/32835

— " $\Sigma v \lambda \lambda \hat{\beta} \beta \delta \eta v$ como reformulador recapitulativo en griego clásico", Ianua Classicorum I 627-634.

\section{MICENOLOGÍA}

Alonso Moreno, C. V.: "Cambios familiares en el mundo micénico en el paso del Heládico reciente IIIb2 al IIIc desde la perspectiva del parentesco”, Ianua Classicorum II 607-613. 
LÓPez Chala, Á.: "Micénico O-WI-DE-TA-I: una nueva revisión”, Ianua Classicorum I 531-538.

Piquero, J.: "Incrustaciones con vidrios de colores en Pilo. Análisis lingüístico y arqueológico de micénico pa-ra-ku-we", Orientalística en tiempos de crisis 285-296.

- "Micénico pa-ra-ku-we y telas pa-ra-ku-ja: una nueva etimología en el contexto del Oriente Próximo", AuOr 33.1, 2015, 115-126.

SACCONI, A.: "L'origine della scrittura nell'Egeo", Ianua Classicorum II 731-738.

\section{EPIGRAFÍA. PAPIROLOGÍA. NUMISMÁTICA}

Albarrán, M. J.: "Las Actas del Concilio de Éfeso del año 431”, La mano del escriba101-106.

Amela Valverde, L.: "El epígrafe dedicado a Cn. Pompeyo Magno en la ciudad de Demetrias (IG IX 2, 1134). El reflejo de la política romana en una ciudad de provincias", SEBarc.13, 2015, 25-33.

Calero Secall, I. M.: "Los epibállontes y los kadestaí en las prescripciones gortinias sobre los entierros", Ianua Classicorum II 631-638.

Capasso, M.: "Carlo di Borbone per la papirologia ercolanese", Ianua Classicorum III 35-41.

Cortés Copete, J. M.: "Adriano y la regulación de los mercados cívicos: una nueva lectura de IG II ${ }^{2} .1103$ ", Habis 46, 2015, 239-263.

Crespo Ortiz de Zárate, S.: "Griegos en la mitad Norte Central de Hispania romana", HAnt.39, 2015, 243-256.

De Frutos García, A.: “Textos documentales y paraliterarios”, La mano del escriba 107-113.

Fernández Delgado, J. A.: "La renovación del Mundo Clásico: veinticinco años de hallazgos en papirología literaria”, Studia Classica Caesaraugustana 137- 164.

Gomis GARCía, V.: "Un documento literario poco convencional: la inscripción de Mnesíepes (fragmento E1II)", Emerita 83, 2015, 111-132.

GonZÁlez Salinero, R.: "El grafito de Alexámeno: recuperando el debate sobre la caricatura anticristiana de Palatino (inv. 381403)", Studia Angelo Urbano dicata 323-340.

- Hispania epigraphica 20 X 2011 (2014). Madrid, Universidad Complutense, 2014.

INDELLI, G.: "I papiri ercolanesi come fonti di autori antichi”, Ianua Classicorum III 43-52.

López PÉrez, M.: Los relatos milagrosos de la Estela A del santuario médico de Epidauro. Monografías y estudios de Antigüedad griega y romana 46. Madrid - Salamanca, Signifer, 2015.

Martín Hernández, R.: "La colección de Papiros Ubach (Papyri Barcinonenses)", La mano del escriba 38-42.

Martínez Bermejo, M. Ll.: "Comentarios y marginalia al texto de Eurípides en los papiros", Ianua Classicorum II 223-230.

Martínez Fernández, Á.: "Inscripciones cristianas de Císamo", Fortunatae 25, 2014, 323-335.

— "Un epitafio inédito de Aptera (Creta)", Homenaje a Ignacio Rodríguez Alfageme 503-508.

Molinos Tejada, M. T.: "Rótulos publicitarios griegos de época helenística", Ianua Classicorum II 239-246.

Nodar Domínguez, A.: "Los papiros homéricos", La mano del escriba 53-68.

Ortega Monasterio, M.T.: "Formación de la colección: el museo y sus manuscritos", La mano del escriba $114-126$.

— “La colección Roca Puig de papiros. Su formación”, La mano del escriba 43-52.

Ramon Tragan, P.: "Ramón Roca Puig (1906-2001)", La mano del escriba 20-29.

Roure, D.: “P. Bonaventura Ubach i Medir (1879-1960)", La mano del escriba 11-19.

Spottorno, M. V.: "Los Bíblicos de Montserrat", La mano del escriba 76-90.

Torallas Tovar, S.: "El códice misceláneo", La mano del escriba 69-75.

- "Injuria y vilipendio en los papiros de época grecorromana", Homenaje a Ignacio Rodríguez Alfageme 781-794. 


\section{HISTORIA DE LOS TEXTOS}

Basbanes, N. A.: De papel. En torno a sus dos mil años de historia. Madrid, FCE, 2014.

Borrás Perelló, Ll.: El libro y la edición. De las tablillas sumerias a la tableta electrónica. Gijón, Trea, 2015.

Bravo García, A.: Viajes por Bizancio y Occidente. Madrid, Dykinson, 2014.

FLoRIstán, J. M.: "El enigmático destino de Nicolás de la Torre, copista griego de Felipe II", Humanismo y pervivencia del mundo clásico V, vol.IV 2153-2172.

Fornas RiEsco, S.: "El manuscrito Ang. Gr.43 en el s.XVI: una reconstrucción del contenido y su disposición", E barbatulis puellisque 163-174.

Gatsioufa, P.: "Notas sobre los manuscritos griegos de la abadía del Sacromonte", Humanismo y pervivencia del mundo clásico $V$, vol.I 287-307.

González CAlderón, J. F.: Historia de la tradición textual del comentario de Alejandro de Afrodisias a los Tópicos de Aristóteles. Tesis doctoral. Universidad Carlos III de Madrid, 2015. https://e-archivo.uc3m.es/handle/10016/20670?locale-attribute=en.

Hernández MuÑoz, F .G.: "Presente y futuro de la crítica textual griega: los manuscritos recentiores. Algunos ejemplos", Ianua Classicorum II 765-772.

Martínez Manzano, M. T.: De Bizancio al Escorial. Adquisiciones venecianas de manuscritos griegos para la biblioteca regia de Felipe II: colecciones Dandolo, Eparco, Patrizi.Mérida, Editora Regional de Extremadura, 2015.

- Historia del fondo manuscrito griego de la Universidad de Salamanca. Salamanca, Universidad, 2015.

— "Formación de la colección: el museo y sus manuscritos", La mano del escriba 114-126.

RAMÓn García, D.: "La tradición manuscrita de las Quaestiones Homericae de Heráclito", Ianua Classicorum II 801-806.

Solana Pujalte, J. E.: "Bibliotecas privadas de los siglos XVI y XVII en la biblioteca del antiguo Colegio de la Asunción de Córdoba", Studia Angelo Urbano dicata 645-667.

URBÁN FERNÁNDEZ, Á.: "La edición y estudio filológico de un manuscrito inédito bilingüe, greco-árabe, del Evangelio de Lucas del siglo XI (BnF, suppl. gr. 911, año 1043): problemática de la edición de textos bíblicos", Europa Renascens 579-606.

\section{HISTORIA. CULTURA. SOCIEDAD}

AA.VV.: Dioses, héroes y atletas. La imagen del cuerpo en la Grecia Antigua. Alcalá de Henares, Museo Arqueológico Regional, 2015.

Alvarado Planas, J.: "Derecho y trifuncionalismo indoeuropeo en la antigüedad", Nómos ágraphos - Nómos éngraphos 11-48.

Barceló, P. - Hernández de la Fuente, D.: Breve historia política de la Grecia clásica. De Clístenes a Pericles. Madrid, Escolar y Mayo, 2015.

BARsotti, R.: Antigua Grecia. Madrid, Edimat, 2015.

Bolen, J. S.: Artemisa. El espíritu indómito de cada mujer. Barcelona, Kairós, 2015.

Bravo García, A.: Viajes por Bizancio y Occidente. Madrid, Dykinson, 2014.

Casado Rigalt, D.: Historia de la educación durante la Antigüedad y la Edad Media. Madrid, UDIMA, 2015.

Citati, P.: Alejandro Magno. Barcelona, Gatopardo, 2015.

Cline, E. H.: 1177 a.C. El año en que la civilización se derrumbó. Barcelona, Crítica, 2015.

De Azara, P. (ed.): Mediterráneo: del mito a la Razón. Barcelona - Madrid, Obra social La Caixa, 2014. 
De Azara, P. (ed.): Mediterrani: del mite a la raó. Barcelona - Madrid, Obra social La Caixa, 2014.

De Hoz, M.P. - Mora, G. (eds.): El Oriente griego en la Península Ibérica. Epigrafía e Historia. Bibliotheca Archaeologica Hispana 39. Madrid, Real Academia de la Historia, 2013.

Fernández García, A. J.: "Las marionetas en la Grecia antigua: un acercamiento", Fortunatae 25, 2014, 129-138.

Freitas do Amaral, D.: Historia del pensamiento político occidental. Barcelona, Atelier, 2014.

Gangutia Elícegui, E.: "Oriente Griego y Extremo occidente Ibérico”, Tempus 38, 2015, 7-34.

García Domingo, E.: "Algunas observaciones sobre la atimía", $C F C G$ 25, 2015, 85-113.

Golvin, J. C.: Ciudades del mundo antiguo, Madrid, Desperta Ferro, 2015.

Gregorio Navarro, M. C. D.: "Violencia de género y privación de libertad en el mundo clásico", Género y enseñanza de la historia 269-290.

Hernández Crespo, R. - Domínguez Monedero, A. J. (eds.): Las edades del hombre. Las etapas de la vida entre griegos y romanos. Madrid, Sociedad Española de Estudios Clásicos, 2014.

Lozano Gómez, F. - Giménez de Aragón Sierra, P. - Alarcón Hernández, C.: "Reyes y dioses:: la realeza divina en las sociedades antiguas", Arys 12, 2014, 9-28.

Megías Quirós, J. - Cabrera Caro, L.: Historia de las ideas políticas. De la democracia griega a la monarquía medieval. Cádiz, Universidad, 2015.

Martínez García, O.: Héroes que miran a los ojos de los dioses. Historia de Grecia desde la edad del bronce hasta el final de la época clásica. Barcelona, EDAF, 2015.

Murcia Ortuño, J.: De banquetes y batallas. Madrid, Alianza, 2014.

Olalla González, P.: Grecia en el aire. Herencias y desafíos de la antigua democracia ateniense vistos desde la Atenas actual. Barcelona, Acantilado, 2015.

Osaba, E.: Derecho, cultura y sociedad en la Antigüedad tardía. Bilbao, Universidad del País Vasco, 2015.

Pascual González, J.: El mundo griego en el siglo IV a.C. Madrid, Pascual González, 2015.

Pérez Martínez, J. A.: Espartanos. Los hombres que forjaron la leyenda. Madrid, Sílex, 2015.

Pohlsander, H. A.: El emperador Constantino. Madrid, Rialp, 2015.

Rubio, S.: Derechos de la mujer en la Antigüedad. Egipto. Grecia. Roma. Barcelona, Última Línea S.L., 2014.

SÁnchez SAnZ, A.: El poder naval de Grecia en el siglo V a.C. Zaragoza, HRM Ediciones, 2015.

Scotт, M.: Delfos. Historia del centro del mundo antiguo. Traducción de F. García Lorenzana. Barcelona, Ariel, 2015.

VidAl, J. - ANTEla - Bernárdez, B. (eds.): Guerra y religión en el mundo antiguo. Zaragoza, Pórtico, 2015.

\section{RELIGIÓN. MITOLOGÍA}

Aguirre Castro, M.: "Caracterización y representación de los fantasmas en la antigua Grecia", Fantasmas, aparecidos y muertos sin descanso 55-66.

Alvar EzQuerra, J.: "Bodas, banquetes y comuniones. Más cornadas da el hambre que los rituales mistéricos", El alimento de los dioses 181-192.

Blanco Cesteros, M.: "La doncella profética: la última metamorfosis de Dafne", Ianua Classicorum II $75-82$.

Buxton, R.: "Fantasmas y religión entre los griegos: contextos y control", Fantasmas, aparecidos y muertos sin descanso 41-54.

Caballero González, M.: "La asimilación del mito de Atamante a los mitos de Medea, Orfeo y Procne", Minerva 28, 2015, 107-132.

Calderón Sánchez, M.: "La catábasis y el ánodos de Perséfone en su iconografia", Europa Renascens 43-62. 
Campbell, J.: Diosas. Misterio de lo divino femenino. Gerona, Atalanta, 2015.

Caparrós, N.: Épica, mito y tragedia. Edipo más allá de Grecia. Madrid, Biblioteca Nueva, 2015.

Chapinal Heras, D.: “Genealogía heroica en el mundo epirota: la monarquía molosa”, Arys 12, 2014, 159-180.

De Cicco, P.: "Rileggendo Eumolpo: un'autoctonia rivisitata", Emerita 83, 2015, 1-22.

Díez de Velasco Abellán, F.: "Los sentidos del epínetro: imaginarios de lo femenino (y lo amazónico) en la Atenas clásica", Ianua Classicorum II 557-584.

DíEz Platas, F.: "El vaso del dios: consideraciones sobre el atributo de Dioniso en la cerámica ática", Ianua Classicorum II 649-664.

Esteban Santos, A.: “Agamenón, Medea y Traquinias: retrato sangriento de tres esposas. Heroínas de la mitología griega V", CFCG 25, 2015, 157-191.

FERNÁNDEZ FERnÁNDEZ, Á.: La iunx mediadora: ornitología, magia amorosa, mitología y teología caldaico-neoplatónica”, $C F C G$ 25, 2015, 223-271.

Ferrer Albelda, E. - Pereira Delgado, Á. (coords.): Hijas de Eva. Mujeres y religión en la Antigüedad. Sevilla, Universidad, 2015.

Fuentes Jiménez, J. R.: “Mythos y religión en el logos presocrático”, Helmantica 66(195), 2015, 133-170.

- Sirenas. Seducciones y metamorfosis. Madrid, Turner, 2014.

García Gual, C.: Historia mínima de la mitología. Los mitos clásicos y sus ecos en la literatura occidental. Madrid, Turner, 2014.

- "Adivinos míticos", Adivinos, magos, brujas, astrólogos 15-28.

García Gual, C. - Hernández de la Fuente, D.: El mito de Orfeo. Estudio y tradición poética. Madrid, FCE, 2015.

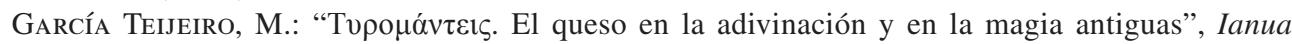
Classicorum II 665-671

García Trabazo, J. V.: "Aproximación al nombre de Ártemis en el contexto del zoomorfismo religioso anatolio", Orientalística en tiempos de crisis 181-190.

GonzÁlez Terriza, A. A.: "Brujas, ogresas y otras mujeres de mal vivir", Adivinos, magos, brujas, astrólogos 127-147.

Graves, R.: Dioses y héroes de la antigua Grecia: explicados a los jóvenes. Traducción de L. Graves. Barcelona, Austral, 2015.

Hay, K.: "La tragedia de Orfeo", De Orfeo a David Lynch 141-144.

Hernández de la Fuente, D.: Mitología clásica. Prólogo de C. García Gual. Madrid, Alianza, 2015.

- "Adivinación ctónica y adivinación apolínea: sobre la evolución del discurso y del espacio sacro en la mántica griega", Adivinos, magos, brujas, astrólogos 79-102.

- "Tres capítulos sobre derecho y religión en la Grecia antigua", Nómos ágraphos - Nómos éngraphos 49-80.

Herrero de JÁuregui, M.: “Aristotechnas", Homenaje a Ignacio Rodríguez Alfageme 367-378.

Jiménez San Cristóbal, A. I.: "De nuevo sobre Dioniso y las serpientes: mitos y ritos", Myrtia 30, 2015, 167-184.

- "Me vengaré desde mi tumba", Fantasmas, aparecidos y muertos sin descanso 83-100.

— "Ríos y lagunas de camino al Hades", Homenaje a Ignacio Rodríguez Alfageme 379-390.

JimÉnez Zamudio, R.: "Un paralelismo acadio del mito de Faetón", Estudios en honor del profesor Vitalino Valcárcel 493-507.

Konstan, D.: "El mito de Orfeo: poética y mitología", De Orfeo a David Lynch 35-46.

LEAL EIMIL, R.: "El origen anatolio del dios Apolo", E barbatulis puellisque 23-34.

López Pardo, F.: “Tingentera, Tingi y el mito de Anteo”, Gerión 33, 2015, 105-113. 
López Salvá, M.: "Los sueños y su interpretación en Grecia”, Adivinos, magos, brujas, astrólogos 45-60.

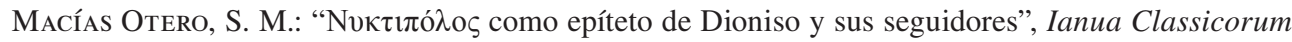
II $215-222$.

Macías Villalobos, C. - Macías Fuentes, D.: "Simbolismo de las aves saturninas en los textos grecolatinos", Europa Renascens 247-296.

Marcos Montiel, J. F.: "Sexo y género en los textos astrológicos de la Antigüedad grecolatina", Europa Renascens 313-326.

Martín Hernández, R.: "¡Yo os conjuro, démones de este lugar! Muertos inquietos y magia amorosa", Fantasmas, aparecidos y muertos sin descanso 67-82.

— "En los límites de la religión: los libros de magia en época grecorromana", Adivinos, magos, brujas, astrólogos 149-173.

Molina Marín, A. I.: "Tifones y gigantes en el mundo macedonio: el rey como símbolo del orden cósmico", Gerión 33, 2015, 67-89.

Molina MuÑoz, P. J.: "El nuevo triunfo de Dioniso: tradiciones y ritos en la Grecia moderna", Ianua Classicorum III 673-679.

- "El travestismo dionisíaco", Tycho 3, 2015, 39-64.

Montañés Gómez, R.: "Caronte en la cultura popular griega", Humanismo y pervivencia del mundo clásico $V$, vol.V 2621-2639.

Moscoso, J.: "Las reglas del infierno", De Orfeo a David Lynch 95-94.

Nissan, E.: "Animals calling out to Heaven: In support of the hypothesis of an Alexandrine Egyptian connection to the animals praising Heaven in Pereq Shirah (A chapter of hymns): Some evidence from Egypt's Greek magical papyri”, $M H N H$ 14, 2014, 167-196.

Notario Pacheco, F.: "Despedazando el sacrificio: lo comible, lo incomible y el descuartizamiento de la víctima sacrificial en el mundo griego", El alimento de los dioses 103-121.

Pagès Cebrián, J.: "El nacimiento de Orión en Euforión de Calcis y en Ovidio: estudio de los orígenes y la tradición de un mito beocio", Emerita 83, 2015, 265-288.

- "La imagen poética del auriga: connotaciones míticas e iniciáticas", Ianua Classicorum II 255262.

Pajón Leyra, I.: "Los dioses en la salud y en la enfermedad: las curaciones milagrosas en el mundo griego", Adivinos, magos, brujas, astrólogos 61-78.

Perea Yébenes, S.: "El voto de un soldado a Silvano - Zeus Dalbenus?", Gerión 33, 2015, 311-324.

Pérez Jiménez, A.: "Religiones orientales e iconografía numismática antigua", Europa Renascens 365-394.

Real Torres, C.: "Fuentes clásicas para el estudio de la Prehistoria: la leyenda del grifo", Fortunatae 25, 2014, 461-473.

Russo, S.: "Espressioni documentarie del culto eroico di Alcmena", Helmantica 66(196), 2015, 9-20.

Sala i Pujolràs, J.: Pelegrinatge al turó de Prometeu: efectes secundaris d'uns èxits inquietants. Barcelona, L'Albí, 2015.

Santamaría Canales, I.: "Isis a través de los textos: el culto isíaco en la literatura grecolatina de época altoimperial", 'Ilu 20, 2015, 231-248.

Schwab, G.: Mitos, cuentos y leyendas de la Antigüedad clásica. Madrid, Verbum, 2015.

SuÁrez de la Torre, E.: "Juan Gil y el fin del mundo", Humanismo y pervivencia del mundo clásico $V$, vol.I 557-573.

Vaello Rodríguez, M. V.: "Un culto de Dioniso en el Calendario de Tórico (SEG 33:147 = NGSL 1)", E barbatulis puellisque 35-50.

VAlderrábano González, I.: "El mito como 'máquina lógica': los ejemplos de Atalanta y Edipo", Antesteria 4, 2015, 61-79. 


\section{CRISTIANISMO}

Ball, H.: Cristianismo bizantino, Córdoba, Editorial Berenice, 2016,

Bermejo Rubio, F.: "La génesis del proceso de divinización de Jesús el Galileo: ensayo de status quaestionis", Arys 12, 2014, 293-320.

Brotons Merino, M. J.: El diablo en la literatura griega del cristianismo primitivo: de los inicios a los padres alejandrinos. Tesis Doctoral, Universidad de Valladolid, 2015. http://uvadoc.uva.es/ handle/10324/16037

Calvo, A.: "La identidad martirial cristiana como modelo de racionalidad en las pertenencias religiosas: Un acercamiento jurídico", Bandue 8, 2014-2015, 97-109.

Chenoll Alfaro, R. R.: Entre el verbo y la palabra: estudios sobre judaísmo y cristianismo. Madrid, Ediciones Clásicas, 2015.

Fernández Ubiña, J. - Quiroga Puertas, A. J. - Ubric Rabaneda, P. (coords.): La Iglesia como sistema de dominación en La Antigüedad Tardía. Granada, Universidad, 2015.

Fontana ElboJ, G.: Los orígenes del Cristianismo en Asia Menor (A 70-135), Barcelona, Universidad de Barcelona, 2015.

Fuertes Martín, F. J.: Santos y demonios. El protagonismo de lo demoníaco en la primera literatura hagiográfica sobre Egipto en la antigüedad tardía. Tesis doctoral. Universidad de Cantabria, 2015. https://repositorio.unican.es/xmlui/handle/10902/7925

Gil Arbiol, C.: "Comida y sexo en el cristianismo naciente", El alimento de los dioses 213-227.

Hall, G. N. L.: Simón Mago. Ensayo introductorio de A. Ferreiro. Traducción y bibliografía complementaria de D. Saura Zorrilla. Estudio introductorio de A. Ferreiro. Madrid - Salamanca, Signifer, 2015.

HubelÑák, F.: "Algunas consideraciones sobre el pasaje de la Romanidad a la Cristiandad", Helmantica 66(195), 2015, 213-230.

KüNG, H.: Jesús. Madrid, Trotta, 2014.

Martínez Maza, C.: "Recursos mágicos paganos en la Iglesia tardoantigua", $M H N H$ 14, 2014, 9-24.

PIÑERO, A.: Jesús y las mujeres. Madrid, Trotta, 2014.

— "El transfondo judío del binitarismo de Pablo de Tarso", Arys 12, 2014, 321-339.

Puente Ojea, G.: Orígenes del credo cristiano. El triunfo de la tergiversación paulina. Madrid-Salamanca, Signifer libros, 2014.

Santos Marinas, E.: "Apostolicidad e identidad religiosa: Los supuestos orígenes apostólicos del cristianismo entre los esclavos orientales", Bandue 8, 2014-2015, 127-136.

SARDElla, T.: "Identità e universalismo: Il cristianesimo come ‘passaporto' di romanità nella tarda antichità", Bandue 8, 2014-2015, 111-125.

TeIXIDor, J.: El judeo-cristianismo. Madrid, Trotta, 2015.

TEJA, R.: 'De ‘cuentos de viejas' a objetos sagrados: La ‘cristianización' del amuleto-phylakterion en la Iglesia antigua", $M H N H$ 14, 2014, 71-96.

Trebolle Barrera, J.: "Formación y desarrollo de la identidad judía antes y después del año 70 D. C.: Líneas de continuidad y de ruptura dentro del judaísmo y entre judaísmo y cristianismo", Bandue 8, 2014-2015, 63-82.

Vicens PedRet, X. M.: "La ordenación de diáconos en la papirología documental", Ianua Classicorum III 71-79.

Vilella Masana, J. (eds.): Constantino, ¿el primer emperador cristiano? Religión y política en el siglo IV, Barcelona, Universidad de Barcelona, 2015.

Wedderburn, A. J. M.: Una historia de losprimeros cristianos. Traducido por F. J. Molina de la Torre. Salamanca, Sígueme, 2015. 


\section{FILOSOFÍA. CIENCIA}

AdDABBo, C.: "Utopie geometriche. Una società a più dimensioni", Imaginarios cientificos 115-128.

Aparicio Villalonga, C.: "La concepción del sabio en el estoicismo y su similitud con el autor del papiro de Derveni", Ianua Classicorum I 213-222.

AskunZe, M. M.: Diálogos con los filósofos griegos: la filosofía griega, desde la perspectiva del siglo XXI. Vitoria, Fundacion Caja Vital Kutxa, 2015.

BASILI, C.: "Simone Weil e la scienza greca: verso l'utopia di una società radicata", Imaginarios científicos 193-208.

Bosch- Veciana, A.: Lectures gregues. Barcelona, Universidad Ramon Llull, 2014.

Decharneux, B.: "Sócrates o la sabiduría demónica", Sócrates. La muerte del hombre más justo I760.

Foucault, M.: Lecciones sobre la voluntad de saber. Curso en el Collège de France (1970-1971) seguido de El saber de Edipo. Edición establecida por D. Defert, bajo la dirección de F. Ewald y A. Fontana. Traducción de H. Pons. Revisión y transliteración de términos griegos de H. Martignone. Madrid, Akal, 2015.

Fuentes Jiménez, J. R.: “Mythos y religión en el logos presocrático”, Helmantica 66(195), 2015, 133-170.

Garrocho Salcedo, D.S.: "La esperanza socrática: filosofía o barbarie", Sócrates. La muerte del hombre más justo I27-I52.

Hernández de la Fuente, D.: "El pitagorismo antiguo entre ciencia y utopía", Imaginarios científicos 165-176.

LLEDó, E.: Fidelidad a Grecia. Edición de M. Jalón. Valladolid, Cuatro Ediciones, 2015.

- Palabra y humanidad. Oviedo, KRK, 2015.

Luri Medrano, G.: ¿Matar a Sócrates? El filósofo que desafía a la ciudad. Barcelona, Ariel, 2015.

Molina Marín, A. I.: "Un nuevo mundo, una nueva geografía", Humanismo y pervivencia del mundo clásico $V$, vol.II 833-848.

Olmos, P.: "Las prosopopeyas en la tradición del enciclopedismo alegórico. Un ensayo sobre retórica científica", Imaginarios científicos 129-164.

Olmos, P. - Pezzoli, F.: "Introducción. Conocimiento, utopía y acción”, Imaginarios científicos 7-17.

Ortega Muñoz, J. F.: Tratado de Filosofía primera. Nuevos estudios de Metafísica a partir de Aristóteles. Málaga, Universidad de Málaga, 2014.

PÉrEZ, L.: "Concepciones sobre la reproducción sexual en Filón de Alejandría y sus antecedentes científicos griegos", CFCG 25, 2015, 273-289.

Pons Olivares, D.: "Los primeros filósofos cínicos frente a algunas creencias órficas y un proverbio pitagórico", Ianua Classicorum I 285-292.

Prieto Esteban, M. J.: Plantas y árboles en el mundo clásico. Madrid, Áurea Clásicos, 2014.

Reguera Rodríguez, A. T.: La medida de la tierra en la antigüedad. León, Universidad, 2015.

Romero Mariscal, L.: "Sócrates", En Grecia y Roma V415-429.

Strathern, P.: Arquímedes y la palanca. En 90 minutos. Madrid, Akal, 2014.

Temporal Oleart, J.: Pensadors de la Grècia arcaica: filosofia i poesía. Tarragona, Obrador Edèndum, 2015.

ÚBEDA Gómez, J.: "Sócrates mosaico", 101-126.

VelázQuez Jordana, J. L.: "El rechazo socrático de la Ley del Talión”, Sócrates. La muerte del hombre más justo $153-170$.

Zamora Calvo, J. M.: “Alcibíades busca tutor: los riesgos del método socrático”, Sócrates. La muerte del hombre más justo199-232. 


\section{PERVIVENCIA. HUMANISMO. HISTORIA DE LA FILOLOGÍA}

Adrados, F. R.: "Recuerdo y elogio de D. Antonio Tovar", Ianua Classicorum I 97-109.

Aguirre Martínez, G.: "Perspectiva del mito clásico en la poesía de José Angel Valente", Humanismo y pervivencia del mundo clásico $V$, vol.V 2363-2368.

Álvarez, J.: "El pensamiento clásico en la poesía española de hoy: El Platón de los poetas", Ph.Canar.20, 2014, 13-25.

Amado Rodríguez, M. T.: “Álvaro Cunqueiro y la "Canción rodia de la golondrina", Humanismo y pervivencia del mundo clásico V, vol.V 2369-2382.

Andújar Cantón, J. I.: "Pervivencia del mundo clásico en El charco de sangre de F. García Pavón", Ianua Classicorum III 543-551.

Andújar Cantón, J. I. - Llodrá Peris, J.M.: "El héroe trágico y el universo épico de John Ford", Europa Renascens 607-622.

Angiol, M. C.: "Dret, Llei i Poder a la història dels Atrides segons P. P. Pasolini”, Ítaca 30, 2014, p. $29-42$.

Arcos Pereira, T. - García de Paso Carrasco, M.D.: "La traducción al latín de algunos términos griegos y su repercusión en los comentarios a los Aphthonii Progymnasmata", CFCL 35, 2015, 319-336.

— "Los Progymnasmata en la obra de Joachimus Camerarius", Ianua Classicorum III 553-560.

Arenas-Dolz, F.: "Fuentes textuales de la lección Einleitung in die Tragödie des Sophocles de Friedrich Nietzsche", Ianua Classicorum I 223-230.

Astorgano Abajo, A.: "Apuntes sobre la perfección clásica en el abate Vicente Requeno (1743-1811), restaurador de artes grecolatinas", Ianua Classicorum III 561-568.

Atienza Valero, S.: "Ópera y mundo clásico: el Faetonte de Lully", Ianua Classicorum III 569-576.

Ávila Salazar, A.: "Epílogo narrativo: Damnatio ad bestias", 183-193.

— "Lo que dice la boca de Orfeo", De Orfeo a David Lynch 121-130.

Badía Fumaz, R.: "La figura de Orfeo como imagen del poeta en Aníbal Núñez", Humanismo y pervivencia del mundo clásico $V$, vol.V 2415-2422.

BAKER-Brian, N.: "El gnosticismo en el cine de ciencia ficción”, Texto, traducción, jacción! 109-113.

Balbuena Torezano, M.C. "Schöne Welt, wo bist du?" Mitología en el Sturm und Drang y el periodo clásico alemán”, Studia Angelo Urbano dicata 65-79.

Belmonte, M.: Peregrinos de la belleza. Viajeros por Italia y Grecia. Barcelona, El Acantilado, 2015.

Beltrán Cebollada, J.A.: "Apuntes para una historia contemporánea de los Estudios Clásicos en la Universidad de Zaragoza (1814-1941)", Studia Classica Caesaraugustana 29-67.

Bermúdez Ramiro, J.: "Personajes mitológicos femeninos en la poesía de Rafael Alberti", Ianua Classicorum III 577-585.

Bermúdez Ramiro, J. - Montañés Gómez, R.: "La traducción al latín de Alessandro Pazzi en el comentario a la Poética de Aristóteles de Francesco Robortello: criterios para su evaluación", Europa Renascens 623-636.

Bilbeny, N - GuÀrdia, J. (eds.): Humanidades e investigación científica. Una propuesta necesaria. Barcelona, Universidad, 2015.

Blasco, S.: El mercader de Alejandría. Sevilla, Algaida, 2014.

Bosch Puche, F.: "Alejandro Magno y el eunuco Bagoas", Texto, traducción, jAcción! 79-87.

Bravo de Laguna Romero, F. J.: "Mundo clásico y crítica social en el teatro del ecuatoriano Peky Andino Moscoso", Humanismo y pervivencia del mundo clásico V, vol.V 2437-2445.

Brioso Santos, H.: “Máximo Brioso Sánchez: in Memoriam”, Habis 46, 2015, 9-19.

Burgos, J. DE: Crónica troyana. Zaragoza, Institución Fernando el Católico, 2015.

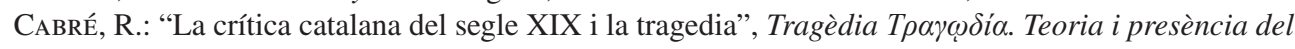
gènere en la literatura catalana 81-158. 
CAlcidio: Traducción y comentario del Timeo de Platón. Introducción, traducción y notas de C. Macías Villalobos. Zaragoza, Pórtico, 2014.

Calvino, I.: Por qué leer los clásicos, Madrid, Siruela, 2015.

Camacho Cuenca, S.: "Influencias clásicas en el Amadís de Gaula", Humanismo y pervivencia del mundo clásico $V$, vol.V 2447-2461.

Campos Daroca, J.: “Apología de Sócrates, según Rossellini”, Texto, traducción, ¡Acción! 53-60.

Camps Gaset, M.: "Heiner Müller i Medea", Ítaca 30, 2014, p. 155-193.

CaÑas Reíllo, J. M.: "La biblioteca grecolatina de Isaac Newton”, Europa Renascens 637-650.

Castignani, H.: "El arte es el poder por el cual la noche se abre: Blanchot y Orfeo el oscuro", De Orfeo a David Lynch 131-140.

Castro Cuadra, A.: La sombra de Dédalo, el toque de Venus. Castellón, Universidad Jaume I, 2015.

Cea Galán, M. J.: "La figura de Agesilao Palmireno en el marco del humanismo español o del laboratorio doméstico del maestro Juan Lorenzo Palmireno", Europa Renascens 651-664.

Clua Serena, J. A.: "La Poètica de l'al-lusivitat en la imatge de la `donna' i de les heroïnes tràgiques gregues a la Commedia del Dant i a l'Infern gòtic català (I)", Ítaca 30, 2014, p. 95-114.

Comesaña López, A. M.: "La cólera de Chuck Nunn Junior: presencia de Homero en un relato de David Foster Wallace", Ianua Classicorum III 587-593.

CRISTóbal López, V.: "Los hombres y las hojas: de Homero a Machado", Myrtia 30, 2015, 285-289.

- "Tradición clásica en Juan del Encina", Humanismo y pervivencia del mundo clásico V, vol.V 2463-2475.

De GoÑ I Echeverría, Í.: “Temática grecolatina en la obra de Lucas José de Elizondo”, Ianua Classicorum III 633-640.

De la Flor, F. R.: "La cítara de Orfeo; la cruz de Cristo: figuraciones de la armonía celeste y de la música de las esferas en la edad moderna hispana”, De Orfeo a David Lynch 47-78.

Del Rincón Sánchez, F. M.: "Las tetas de Tiresias: un drama y una ópera sobre el adivino que cambió de sexo", Ianua Classicorum III 739-746.

De Miguel Mora, C.: "Aristóteles, Escalígero y Weinberg", Humanismo y pervivencia del mundo clásico $V$, vol.III 1339-1349.

Demont, P.: "El motivo de lo 'tardío' en La muerte en Venecia de Thomas Mann y la puesta en escena de las referencias a la Antigüedad", EClás.147, 2015, 5-28.

DíEZ YÁÑEZ, M.: El noble virtuoso. Recepción de la ética aristotélica en la Castilla tardomedieval y renacentista. Tesis Doctoral. Universidad Complutense de Madrid, 2015. http://eprints.ucm.es/33240/

Domínguez Domínguez, J.F.: "Arias Montano y Guillaume Postel”, SPhV 17, 2015, 139-158.

Esteban Santos, A.: Carta a tres esposas trágicas. Madrid, Dyana Arte, 2014.

- Cuando los monstruos dominaban la tierra. Tragicomedia. Madrid, Dhyana Arte, 2015.

Estefanía Álvarez, D.: “Un Antonio Tovar más cercano", Ianua Classicorum I 111-117.

Fernández, A.: Aquellos dioses del Olimpo. Una aproximación literaria a la pintura mitológica del Museo del Prado. Valencia, Pasión por los libros, 2014.

Fernández Galván, A. I.: "La tradición clásica en la obra narrativa de K. E. Tsirópulos: Escila y Caribdis", Ianua Classicorum III 595-602.

Ferri-Benedetti, F.: "Metastasio adaptado para el teatro español: el caso de la Issipile", Humanismo y pervivencia del mundo clásico $V$, vol.V 2501-2523.

Fimiani, Chr.: "Trois lectures du mythe d'Orphée dans la poésie néo-latine: Pétrarque (Bucolicum carmen), Politien (Siluae), Pontano (Urania, Eciogae)", Europa Renascens 665-686.

Fuente Cornejo, T. - Llera Fueyo, L. A.: "Observaciones a las anotaciones a la Poética de Aristóteles del humanista valenciano Pedro Juan Núñez", Humanismo y pervivencia del mundo clásico $V$, vol.III 1247-1255.

Fuentes González, P. P.: “El 'perro filósofo' y Diógenes el cínico en El mundo de Sofía”, Texto, traducción, jAcción! 61-71. 
Galindo Esparza, A.: El tema de Circe en la tradición literaria: de la épica griega a la literatura española. Murcia, Universidad, 2015.

Gallego Pérez, M. T.: "Presencia de la tradición clásica en Lucas Fernández", Ianua Classicorum III 345-353.

García Amorós, M.: "Las Fedras de Eurípides y de Jules Dassin: la Fedra piadosa frente a la Fedra pasional", Texto, traducción, jAcción! 43-51.

García Bueno, C.: "Una traducción latina anónima de los comentarios de Arriano a Epicteto", Ianua Classicorum III 355-361.

García Gual, C.: "La decisión de Orfeo (según Cesare Pavese)", De Orfeo a David Lynch 79-84.

— "Muerte de Alejandro (una interpretación medieval)", Studia Classica Caesaraugustana 375-386.

García Jurado, F.: "La metamorfosis de la Tradición Clásica, ayer y hoy", Studia Classica Caesaraugustana 69-110.

García Jurado, F. - Salazar Morales, R.: La traducción y sus palimpsestos. Borges, Homero y Virgilio. Madrid, Escolar y Mayo, 2014.

García Teijeiro, M.: "La tradición clásica en Gonzalo de Berceo", Studia Angelo Urbano dicata 269-281.

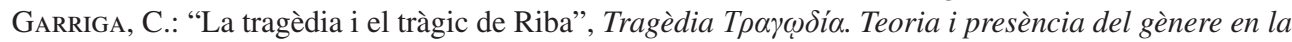
literatura catalana 289-310.

Garrigasait Colomés, R.: L' hàbit de la dificultat: Wilhelm von Humboldt i Carles Riba davant l'Agamèmnon d'Èsquil. Barcelona, Mateo Triguero Rubia, 2015.

Gil Fernández, J.: 300 historias de palabras. Cómo nacen y llegan hasta nosotros las palabras que usamos, Madrid, Espasa Libros, 2015.

- "El Mundo Clásico en la poesía de los Argensola", Studia Classica Caesaraugustana 387-464.

- "A cuento del centenario del texto griego de la Poliglota complutense", CFCG 25, 2015, 291-300.

Gilabert BarberÀ, P.: "Greek de Steven Berkoff (1980): l'arriscada conversió de l'Èdip rei de Sòfocles en una love story”, Ítaca 30, 2014, p. 135-154.

GonZález Arenas, M. I.: "La construcción paródica del mito de la caverna en el s. XX: de Platón a Virgilio Piñera", Ianua Classicorum III 613-620.

González Calderón, J. F.: Historia de la tradición textual del comentario de Alejandro de Afrodisias a los Tópicos de Aristóteles. Tesis doctoral. Universidad Carlos III de Madrid, 2015. https://e-archivo.uc3m.es/handle/10016/20670?locale-attribute=en

GonzÁlez Delgado, R.: "Primeras traducciones del griego a lengua asturiana", Humanismo y pervivencia del mundo clásico $V$, vol.II 1003-1017.

GonzÁlez Manjarrés, M. Á.: "Un testimonio de humanismo médico: las epístolas nuncupatorias de Jano Cornario a sus traducciones latinas de Hipócrates y Pablo de Egina”, Ianua Classicorum III 371-378.

González Pérez, L.: "Nature and Culture in Tony Harrison's The Trackers of Oxyrhynchus", Tycho 3, 2015, 5-24.

GonzÁlez Vaquerizo, H.: "El poeta es un fingidor y los cretenses no dejan de mentir: de las mentiras del Ulises homérico a la Odisea de Nikos Kazantzakis", Ianua Classicorum III 621-631.

- "La tradición clásica en los cantautores españoles y brasileños: denuncia y crítica social", Minerva 28, 2015, 341-361.

Gutiérrez García, J. L.: Apuntes para una historia de la Biblioteca de Autores Cristianos. Madrid, CEU Ediciones, 2014.

Guzmán Almagro, A.: "La magia amorosa y sus fuentes clásicas en Martín del Río (Disquisitionum magicarum libri VI, III.3)", Humanismo y pervivencia del mundo clásico V, vol.IV 2189-2199.

Guzmán García, H.: "Eurípides en la ópera: Le Sconfitte de Claudio Gay", Ianua Classicorum III 649-656.

— "Ulises y Circe en la escena de la ópera cómica francesa del siglo XVIII", Europa Renascens 709-718. 
Hernández de la Fuente, D.: "Sobre la figura de Hipatia de Alejandría en las fuentes literarias y en Ágora", Texto, traducción, jAcción! 115-123.

HernándeZ Miguel, L. A.: "La tragedia griega en el teatro y en el cine de los siglos XX y XXI", $L a$ vida a escena 178-195.

Herrera Roldán, P. P.: "Sobre helenismos en textos literarios mozárabes", Studia Angelo Urbano dicata 373-386.

Hinojo Andrés, G.: "Influencias clásicas en el Libellus de medicinalibus Indorum herbis", Humanismo y pervivencia del mundo clásico $V$, vol.II 709-737.

Homar, R.: "El tràgic en els relats d'amor i d'aventures", Tragèdia T $\rho \gamma \omega \delta i \alpha$. Teoria i presència del gènere en la literatura catalana 25-46.

Hualde Pascual, P.: "Nuevos datos sobre traducciones de novela griega en España durante el siglo XIX”, Myrtia 30, 2015, 255-268.

Ibáñez Chacón, Á.: "Ciane de Siracusa, o Las Bacanales de Cándido María Trigueros: argumento mitológico y fábula impleja", Europa Renascens 719-742.

- "Los Parallela Minora en la tardición escoliástica”, E barbatulis puellisque 149-162.

ILlán CALDERón, I.: "Hacer los deberes. Humanismo e innovación para la pervivencia democrática", Humanismo y pervivencia del mundo clásico $V$, vol.V 2555-2567.

Jiménez del Castillo, J. C.: "Las profecías de la Austriaca siue Naumachia de Francisco de Pedrosa”, Europa Renascens 743-758.

Jiménez Justicia, L.: "El héroe fracasado: Hércules y el establo de Augías de Friedrich Dürrenmatt", Ianua Classicorum III 657-663.

- "La tragedia de la identidad humana: del Edipo Rey de Sófocles a Incendies de Denis Villeneuve", Texto, traducción, ¡Acción! 25-33.

JuAnMartí Generès, E.: D’Israel (1929) a Antígona (1939). L'apropiació espriuana de mites bíblics $i$ clàssics, entre la llum i el neguit. Tesis doctoral. Universitad Autónoma de Barcelona, 2015. http:// www.tdx.cat/handle/10803/326456

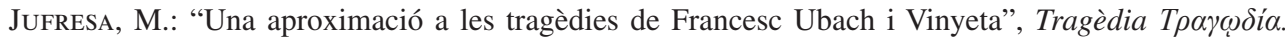
Teoria i presència del gènere en la literatura catalana 159-192.

Kovarskaya, Y.: "Querelle des Anciens et des Modernes en la estética literaria rusa del siglo XIX", Europa Renascens 759-764.

- La Ulixea de Homero, traducida de griego en lengua castellana por el secretario Gonzalo Pérez. Primera traducción de la Odisea al castellano, por Gonzálo Pérez, secretario de Felipe II en endecasílabos sin rima. 2 vols. Málaga, Universidad, 2015.

LeCH, I.: "Visiones y resonancias órficas", De Orfeo a David Lynch 167-182.

Ledesma Pedraz, M.: "El helenismo del emperador Adriano en Mémoires d' Hadrien de Marguerite Yourcenar", Humanismo y pervivencia del mundo clásico V, vol.V 2569-2582.

Lessing, G. E.: Laocoonte. Traducción de E. Barjau Riu y preparación de A. Molina Flores. Madrid, Tecnos, 2015.

Linares SÁnchez, J. J.: "La nekyia en Percy Jackson o cómo evocar a los muertos con una hamburguesa", EClás.148, 2015, 47-68.

Lledó Cardona, M. Á.: "La impronta humanista en la obra del ilustrado valenciano Mariano Madramany y Calatayud", $S P h V 17,2015,237-255$.

Llera Fueyo, L. A.: "Notas al griego de las Anotaciones a la Poética de Aristóteles de Pedro Juan Núñez", Ianua Classicorum III 379-386.

Llevadot, L. - Revilla, C. (eds.): Interpretando a Antígona. Barcelona, UOC, 2015.

Llorca Berrocal, V.: Sota el signe de l'Odissea. El viaggio in Italia del cinema modern: de Rossellini $a$ El menyspreu. Barcelona, Universidad Pompeu Fabra, 2015.

Lojendio Quintero, M. P. - Salas Salgado, F.: "Madrid por dentro de Cristóbal del Hoyo o la erudición clásica en el siglo XVIII", Humanismo y pervivencia del mundo clásico V, vol.V 2583-2592. 
López Calahorro, I.: “La sombra de Grecia y Roma en la obra poética de José Hierro", Europa Renascens 765-774.

López Férez, J. A.: "Del Filoctetes de Sófocles a Demasiado tarde para Filoctetes de Alfonso Sastre: huellas de la tragedia sofoclea e innovaciones", Homenaje a Ignacio Rodríguez Alfageme 429-440.

- "Mitos y nombres míticos clásicos en la General Estoria de Alfonso X (primera y segunda partes)", Ianua Classicorum III 469-525.

LóPEZ FonseCA, A.: "Las mujeres que perdieron la guerra en la escena española del siglo XX: Hécuba y Las Troyanas de Eurípides", Homenaje a Ignacio Rodríguez Alfageme 441-450.

López Rodríguez, C.: "La mirada de Odiseo", Texto, traducción, jAcción! 9-15.

Macarro Fernández, J.: La recreación de los poderes imperiales antiguos de la India. Alejandro Magno y Ashoka en las filmografías india y americana. Tesis doctoral. Universidad de Granada, 2015. http://digibug.ugr.es/handle/10481/41669\#.WI4h09ThDGg

Macía Aparicio, L. M.: "La primera edición de la Ilíada publicada en España", Ianua Classicorum II 761-764.

Macías Fuentes, D.: “Una Medea cubana: la versión de Reinaldo Montero”, Europa Renascens 775792.

Macías Villalobos, C.: "El mundo clásico en el teatro de Unamuno: su versión del mito de Fedra", Estudios en honor del profesor Vitalino Valcárcel 575-594.

Magenis, H.: "Órficas", De Orfeo a David Lynch 145-152.

MagGi, A.: Muerte en la Acrópolis. Barcelona, Duomo, 2015. 13.

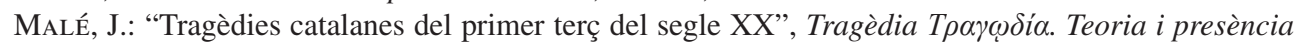
del gènere en la literatura catalana 193-226.

Marco Simón, F.: "Formas de apropiación y reutilización simbólicas en el Mundo Antiguo: espacios e imágenes", Studia Classica Caesaraugustana 341-371.

Marcos Hierro, E.: “La Querella de l'Alceste: Eurípides corregit per Quinault i Lully”, Ítaca 30, 2014, p. 115-134.

Mariscal de Gante Centeno, C.: "Juan Antonio González Iglesias: la recepción clásica en un poeta alejandrino posmoderno", CFCL 35,2015, 337-361.

Márquez Cruz, M.: "La Oratio in funere Iohannis Strozzi de Leonardo Bruni y la oración fúnebre de Pericles recogida por Tucídides: ¿sólo inspiración retórica?”, Humanismo y pervivencia del mundo clásico $V$, vol.III 1315-1326.

Martín de la Hoz, J. C. - Fernández Fernández, E.: "Un humanista en la corte de los Reyes Católicos: Juan López de Palacios Rubios", Humanismo y pervivencia del mundo clásico V, vol.II 819-831.

Martín Ferreira, A. I.: "Transmisión e innovación del saber en la pediatría moderna: El tratado De morbis puerorum de Girolamo Mercuriale (Venecia 1583)", SPhV 17, 2015, 187-216.

Martín Ferreira, A. I. - De la Rosa Cubo, C.: "Antiguos y modernos en los orígenes de la pediatría y la ginecología modernas: el Liber de affectionibus puerorum de Francisco Pérez Cascales (1611)", Humanismo y pervivencia del mundo clásico V, vol.IV 1991-2007.

Martínez Cabezón, E.: "Medea la encantadora: la figura de la hechicera en las novelas de caballerías", Humanismo y pervivencia del mundo clásico V, vol.V 2593-2606.

Martínez Díez, A.: "El Aristófanes de Marcelino Menéndez Pelayo", Homenaje a Ignacio Rodríguez Alfageme 493-502.

Martínez Ezquerro, A.: "El locus amoenus o la creación de un espacio utópico: tradición clásica en la publicidad actual", Ianua Classicorum III 665-672.

Martínez Fernández, I.: "Reflexiones en torno al Mundo Antiguo y a la enseñanza de las lenguas clásicas en la obra de Miguel de Unamuno (dos manuscritos de la Casa Museo Unamuno sobre la enseñanza del latín)", EClás.147, 2015, 97-116.

Martínez Hernández, M.: "La tradición clásica en Cristóbal Pérez del Cristo (1639-1705): mito e historia”, Fortunatae 25, 2014, 315-322. 
Martínez MazA, C.: "El mundo clásico en la forja de una nueva nación: apodos grecorromanos en los albores de los EEUU (1776-1790)", Europa Renascens 825-852.

Martínez Prieto, R.: "Empleo de fuentes en el Libro de theriaca (Toledo, 1575) del boticario Lorenzo Pérez: un posible testimonio del humanismo médico toledano", E barbatulis puellisque 223-236.

Merke, H.: "El Quijote Cervantino como respuesta al Eutidemo de Platón. Sobre mentira y contradicción", Humanismo y pervivencia del mundo clásico V, vol.V 2607-2619.

Miranda Cancela, E.: "Antígona en las Antillas", Ianua Classicorum III 529-540.

Molina SÁnchez, M.: "El teatro humanístico español: claves para su estudio", Europa Renascens 853-882.

Molinos Tejada, M. T. - García Teijeiro, M.: "La sangre de dragón y el drago”, Fortunatae 25, 2014, 363-372.

Montes Cala, J. G. -Fernández Montañez, M. P.: "Luis Cernuda, lector de Platón en Glasgow. Trazas del Fedro en la primera edición de Ocnos", Homenaje a Ignacio Rodríguez Alfageme 581-598.

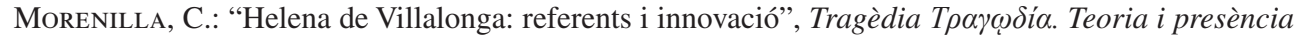
del gènere en la literatura catalana 311-332.

Moscoso, J.: "Las reglas del infierno", De Orfeo a David Lynch 95-94.

MoYa DEL BAÑo, F.: Quevedo y sus ediciones de textos clásicos. Las citas grecolatinas y la biblioteca clásica de Quevedo. Murcia, Universidad, 2014.

— “Don Francisco de Quevedo, 'filo-filólogo' clásico", Humanismo y pervivencia del mundo clásico V, vol.I 185-209.

Moya del Baño, F. - Gallego Moya, E.: “La vida de Anacreonte y el trabajo `filológico’ de Quevedo", Homenaje a Ignacio Rodríguez Alfageme 599-620.

Munaro, M.: "Dionisio o Penteo? Il lavoro sullo spettatore nel Teatro de Lemming”, Ítaca 30, 2014, p. 223-229.

Muñoz García de Iturrospe, M. T.: "Fantasmas y daemones litterati: apariciones de muertos insignes desde la Antigüedad", Fantasmas, aparecidos y muertos sin descanso 117-130.

Narro, Á.: "Les versions françaises médiévales du Physiologos et la description de la licorne", Bestiaris i metamorfosis 109-120.

Nascimento, A. A.: "Humanismo, uma atitude mais que um momento na história", Humanismo y pervivencia del mundo clásico V, vol.IV 2093-2115.

NAVARro SÁnchez, F.: "Aristóteles Latinus en las Questiones super libro de animalibus Aristotelis de Pedro Hispano", Ianua Classicorum III 287-294.

Nicholson, A.: El eterno viaje: cómo vivir con Homero. Traducción de G. Deza Guil. Barcelona, Ariel, 2015.

Nieto Caballero, G.: "Referencias clásicas en el legado de Francisco Valdés, un escritor extremeño en la Edad de Plata", Myrtia 30, 2015, 269-282.

Nieves Sanza, E. J.: "Citas de los cuatro grandes Padres Orientales de la Iglesia en la obra de D. Martín Pérez de Ayala (1504-66), De divinis, apostolicis atque ecclesiasticis Traditionibus", Studia Angelo Urbano dicata 503-536.

Ortega Garrido, A.: "Las ninfas clásicas en los poetas del grupo del 27", Ianua Classicorum III 681-690.

- "Materiales clásicos en Exorcismos de esti(l)o de Guillermo Cabrera Infante", Humanismo y pervivencia del mundo clásico $V$, vol.V 2641-2649.

Paduano, F.: "L'ironia tragica nell'Antigone (con una nota sull'Antigone di Salvador Espriu)",

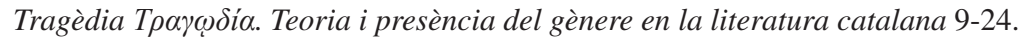

Palomar, N.: "L'Edipo dei Mille (M. Munaro): atreverte a una iniciación mistérica”, Ítaca 30, 2014, p. 195-221.

Paniagua Pérez, J.: “Animales y mitos clásicos en Indias”, Humanismo y pervivencia del mundo clásico $V$, vol.II 753-775. 
Pascual Barciela, E.: El motivo de la anagnórisis en la tragedia grecolatina y en la española del Renacimiento. Tesis doctoral. Universidad de Burgos, 2015.

Pascual López, X.: "El conformismo como motivo grecorromano en las paremias españolas", Paremia 24, 2015, 31-42.

Pedraza, P.: "Orfeo y Eurídice: el viudo en el laberinto", De Orfeo a David Lynch 95-116.

Pedrero SAncho, R.: "Ópera y novela griega: las Etiópicas de Heliodoro", Ianua Classicorum III 691-697.

Penadés Chust, A.: Tras las huellas de Heródoto. Córdoba, Almuzara, 2015.

Pérez Custodio, M. V.: "La recepción de los ejercicios retóricos del Pseudo-Hermógenes en la España del XVI", Humanismo y pervivencia del mundo clásico V, vol.III 1351-1364.

Pérez Gómez, L.: "El coro de la tragedia, comentarista invitado en Mighty Aphrodite de Woody Allen”, Texto, traducción, ;Acción! 89-99.

PÉrez i DurÀ, J.: "Los escritores clásicos, soporte de las críticas de los diaristas a Gregorio Mayans", Humanismo y pervivencia del mundo clásico V, vol.IV 1869-1896.

PÉrez IbÁÑEz, M. J.: "António Luiz, aproximación a un médico humanista”, Humanismo y pervivencia del mundo clásico V, vol.IV 2009-2022.

Pérez Lasheras, A.: “Algo más sobre la tradición clásica en Góngora”, Humanismo y pervivencia del mundo clásico $V$, vol.V 2331-2345.

Pérez Zúñiga, E.: "La Ciencia platónica de Giuseppe Tartini”, De Orfeo a David Lynch 117-120.

Pestano Fariña, R.: "El creador alusivo. Teseo en los Andes", Fortunatae 25, 2014, 423-431.

Pimentel, M. C.: "Leena y Epícaris, dos ejemplos de valor femenino", Europa Renascens 883-900.

Pino Campos, L. M.: "La obra jurídica de Solórzano y las citas de Galeno", Homenaje a Ignacio Rodríguez Alfageme 665-676.

— "Las fuentes clásicas del jurista Juan de Solórzano Pereira", Ianua Classicorum III 699-706.

Platas Romero, R.: "El uso de las fuentes clásicas en el libro II de De bello hereticorum del Fortalitium Fidei de Alfonso de Espina”, Humanismo y pervivencia del mundo clásico V, vol.II 849-858.

Plaza Picón, F. M. - González Doreste, D. M. - Aguiar Aguilar, M.: "Venus ante el espejo: de Homero a Jean de Meun", Fortunatae 25, 2014, 447-459.

PociÑa Pérez, A.: Medea, Safo, Antígona. Tres piezas dramáticas. Granada, Esdrújula Ediciones, 2015.

Pö̈TE, M.: Introducción al urbanismo. Evolución de las ciudades. Lecciones de la antigüedad. Traducción de M. Moro Vallina. Oviedo, KRK, 2015.

Pombo Gallego, N.: "La representación cinematográfica de la cultura minoica", Ianua Classicorum III 707-714.

Pomer Monferrer, L.: "El episodio del encuentro de la amazona Talestris con Alejandro: fuentes y transmisión”, Ianua Classicorum III 715-720

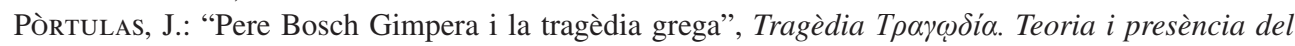
gènere en la literatura catalana 227-268.

Puchal Terol, V.: El héroe Crusoe: modernización del mito de Ulises en el siglo XIX”, Tycho 3, 2015, 65-80.

Puyadas RupéRez, V.: "El Egipto grecolatino en las manifestaciones pictóricas del s. XVIII: Cleopatra VII en la obra de Angelika Kauffmann", Humanismo y pervivencia del mundo clásico V, vol.V 2651-2657.

- "La influencia clásica en la elaboración de la imagen femenina en la literatura del Siglo de Oro. Cleopatra VII y Baltasar Gracián", Género y enseñanza de la historia 345-366.

Querol SAnz, J. M.: La imagen de la Antigüedad en tiempos de la Revolución Francesa. Gijón, Trea, 2015.

Quiroga Puertas, A. J.: "Descensus ad Solaris", Texto, traducción, jAcción! 73-78.

Redondo Moyano, E.: "Gore Vidal y su recreación novelesca de Juliano el Apóstata”, Humanismo y pervivencia del mundo clásico V, vol.V 2659-2671. 
ReXroth, K.: Cita con los clásicos. Logroño, Pepitas de Calabaza, 2014.

Ritsos, Y.: Orestes. Traducción de S. Ancira. Barcelona, Acantilado, 2015.

Robortello, F.: Comentario a la Poética de Aristóteles, Castellón, Universidad Jaume I, 2016.

Rodríguez Díaz del ReAl, A.: "La antigua Grecia en María Zambrano", Europa Renascens 929-942.

Rodríguez Horrillo, M. Á.: "El De Xenophonte historico de Friedrich Creuzer y las causas de la decadencia de la historiografía griega", Europa Renascens 943-958.

Romero Mariscal, L.: "Medea: de Eurípides a Pasolini “, Texto, traducción, jAcción! 17-24.

Rosa Silvestre, L.: "Nietzsche y Wagner: Renacimiento de la tragedia griega", AFAM 5, 2015, 1-14.

Rubio, F. G.: "Lo que la verdad esconde. La liturgia del no retorno", De Orfeo a David Lynch 153-166.

SACRÉ, Th.: "De bellis Pygmaeorum iocosis sive de argumento antiquo quod in carmen heroicocomicum sive poema ludicrum convertit Iacobus Moireau poeta (saec. XVII)", Europa Renascens 975-1000.

SÁEZ, A. J.: "Ecos y referentes clásicos en el Coloquio de los perros de Cervantes", Humanismo y pervivencia del mundo clásico $V$, vol.V 2701-2716.

Salas Salgado, F. - Lojendio Quintero, M.P.: "Mitología clásica e ilustración: Madrid por dentro de Cristóbal del Hoyo", Ianua Classicorum III 747-754.

Salvador Ventura, F.: "Epílogo. Una reconsideración de la presencia del cine histórico en las Facultades de Letras", Texto, traducción, ;Acción! 125-127.

Sánchez de la Torre, A.: Yo, Sócrates. Mis últimas 30 noches. Madrid, Ediciones Clásicas, 2014.

SÁnCheZ-Lafuente Andrés, Á.: "Las influencias grecolatinas en Palimpsesto azul de R. Guarino", Myrtia 30, 2015, 293-302.

SÁnchez Manzano, M. A.: "El uso de la terminología y doctrina retórica en la edición que hizo H. Alonso de Herrera de los Rhetoricorum libri de Jorge de Trebisonda", Humanismo y pervivencia del mundo clásico $V$, vol.III 1365-1381.

Sánchez Pérez, C.: "La recepción del Corpus Hermeticum en Promethea de Alan Moore", E barbatulis puellisque 275-282.

Sancho Rocher, L. (ed.): La Antigüedad como paradigma. Espejismos, mitos y silencios en el uso de la historia del mundo clásico por los modernos. Zaragoza, Universidad de Zaragoza, 2015.

Santana Henríquez, G.: "La figura de Hipermestra en el teatro francés del siglo XVIII: a propósito del tratamiento del mito de las Danaides en la tragedia Hypermestre (1758) de Antoine-Marie Lemierre", Fortunatae 25, 2014, 499-506.

- "La tradición clásica en la producción literaria de Torres Naharro I (los Capítulos y las comedias Seraphina y Trophea)", Homenaje a Ignacio Rodríguez Alfageme 741-752.

Santamaría Hernández, M. T.: "Testimonios de la traducción latina antigua del De plantis atribuido a Tésalo de Tralles en la versión del Herbario pseudoapuleyano del manuscrito de Wrocław, Biblioteka Uniwersytecka, III F. 19", Myrtia 30, 2015, 99-117.

SaYlor, S.: Las siete Maravillas. Una novela del Mundo Antiguo. Madrid, La esfera de los libros, 2014.

Sebastià SÁez, M.: "Manuel Lassala como dramaturgo neoclásico del Settecento: de Ifigenia a Andrómaca“, Europa Renascens 1023-1034.

Serrano Cueto, A.: Después de Troya: microrrelatos hispánicos de tradición clásica. Palencia, Menoscuarto, 2015.

Senes Rodríguez, G.: "El vuelo del Fénix: de los clásicos a los Hieroglyphica de P. Valeriana y la tradición simbólico-emblemática", Europa Renascens 1035-1050.

Signes CodoÑer, J.: "Bizantinística y filología griega: consideraciones metodológicas y perspectivas de futuro", Ianua Classicorum III 83-115.

- "Homero en tierras del Islam en el siglo IX: Una presencia quizás no tan episódica", Estudios en honor del profesor Vitalino Valcárcel 1005-1020.

SILES, J.: “Antonio Tovar, entusiasmo y generosidad”, Ianua Classicorum I 129-137. 
Solana Pujalte, J. E. - García Pinilla, I. J.: "Erratas y correcciones manuscritas de autor en la traducción latina de la Política de Aristóteles de Juan Ginés de Sepúlveda editada por Michel de Vascosan (París, 1548) (II): los escolios”, Humanismo y pervivencia del mundo clásico V, vol.II 1019-1036.

StrosetzKi, C. (ed.): La autoridad en la Antigüedad. Madrid -Frankfurt, Iberoamericana, 2014.

SuÁrez Martínez, L.M.: "Culturalismo y cultura grecolatina en dos poemas de Syrtes de Luis Antonio de Villena", Ianua Classicorum III 775-782.

Talavera Esteso, F. J.: "Pierio Valeriana y la filología clásica", Europa Renascens 1051-1078.

Terol Plá, G.: "El erudito en el prólogo de No me fastidies, Electra, de Antonio Aguilera Vita", Tycho 3, 2015, 109-134.

Tovar, C. - Tovar, S. - Torallas Tovar, S.; "Antonio Tovar, padre, abuelo, amigo", Ianua Classicorum I 119-127.

VAlverde Abril, J. J.: "Los Apophthegmata de Conrado Licóstenes y la Collectanea moralis philosophiae de Fray Luis de Granada: un camino de ida y vuelta", Humanismo y pervivencia del mundo clásico $V$, vol.IV 2241-2258.

Valverde García, A.: "De Eurípides a Cacoyannis: la despedida de Andrómaca y Astianacte en Las Troyanas", Texto, traducción, ¡Acción! 34-41.

VÁzQuez Buján, M. E.: "Ydropem insanabilem. Una denominación tardolatina de la diabetes", Homenaje a Ignacio Rodríguez Alfageme 795-808.

Vela Tejada, J.: "Tradición clásica e intransigencia religiosa en el teatro de Francisco Bances Candamo", Homenaje a Ignacio Rodríguez Alfageme 809-819.

Vicente Sobradillo, D.: "Los bucólicos griegos en la narrativa japonesa del siglo XX: El rumor del oleaje de Yukio Mishima", Ianua Classicorum III 791-798.

Vidal PÉREZ, J. L.: "Mendelssohn, intérprete de Sófocles", Humanismo y pervivencia del mundo clásico $V$, vol.V 2347-2361.

Villalba de la Güıda, I.: "Los viajes de Odiseo, Eneas y los Argonautas como modelos de las epopeyas neolatinas de tema colombino", Ianua Classicorum III 459-465.

Villanueva.: Así habló Penélope. Alcalá de Henares, Universidad, 2014.

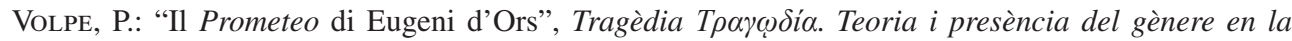
literatura catalana 269-288.

— "La Fedra di Miguel de Unamuno: dall'accusa al perdono", Ianua Classicorum III 799-808.

\section{DICCIONARIOS. REPERTORIOS. OTROS INSTRUMENTOS}

Alberich Mariné, J. - Cuartero Iborra, F. (eds.): Diccionari grec-català. D'Homer al segle II d.C. Coordinació de J. Granados Serrat. Barcelona, Enciclopèdia Catalana - la Fundació Institut Cambó, 2015.

Balz, H. - Schneider, G. - Pulido, J.: Vocabulario Griego del Nuevo Testamento. Edición revisada y ampliada, con nuevo vocabulario español-griego. Salamanca, Sígueme, 2015.

Contreras Valverde, J.: Calendario Clásico Grecorromano. Agenda 2016. Madrid, Ediciones Clásicas, 2015.

Cortés Gabaudan, F. - Ureña Bracero, J.: "Presentación del Dioscórides Interactivo", Ianua Classicorum II 107-113.

EsTÉvez Rodríguez, M. Á.: Etimología grecolatina. Diccionario con prefijos, sufijos, léxico, dobletes y locuciones latinas. Madrid, Círculo Rojo, 2015.

Golobardes, G.: Diccionari Grec-clàssic-Català. Barcelona, Publicaciones de la Abadía de Montserrat, 2015. 
Marcos García, J. J.: Tipografía del griego clásico. Análisis e historia desde la invención de la imprenta hasta la era digital. Madrid, Dykinson, 2014.

Rodríguez Somolinos, H.: "Publicaciones sobre Filología Griega en España (2013-2014)”, Epos 31, 2015, 541-604.

Verdejo MANchado, J.: Léxico de los cómicos griegos fragmentarios de la transición de los ss. V-IV a.C. (AlcaeusComicus - Theopompuscomicus). Oviedo, Eikasia, 2015.

\section{DIDÁCTICA}

AA.VV.: Cuaderno de traducción. Griego. Bachillerato. Proyecto Saber Hacer. Madrid, Santillana, 2015.

AA.VV.: Día a día en el aula. Griego. Bachillerato. Proyecto Saber Hacer. Madrid, Santillana, 2015

Artés Hernández, J. A.: "La enseñanza del Griego II en el Bachibac", Thamyris 6, 2015, 17-34.

Bergua CAVero, J.: Pronunciación y prosodia del griego antiguo: guía práctica para la lectura de sus textos. Madrid, Ediciones Clásicas, 2015.

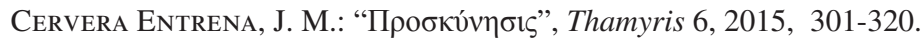

EnCinas Reguero, M.C.: "Los mitos griegos en la literatura infantil y juvenil del s. XIX”, Thamyris $6,2015,87-110$.

García Gual, C. - Lucas de Dios, J. M. - Morales Otal, C.: Griego. Serie Descifra. Bachillerato. Proyecto Saber Hacer. Madrid, Santillana, 2015.

García Navarrete, M. Á. - Navarrete Orcera, A. R.: "La mitología clásica en los museos de Australia", Thamyris 6, 2015, 441-469.

- Griego. Selectividad 2014. Pruebas De Acceso A La Universidad. Madrid, Anaya, 2015.

Husillos García, M. L.: "Las etiquetas de vino como herramienta didáctica para la enseñanza de la Cultura Clásica en la LOMCE”, Thamyris 6, 2015, 347-363.

LiLlo Redonet, F.: "Tocando la escuela grecorromana: papiros, óstraca y tablillas escolares en el aula de Griego y Cultura Clásica", Thamyris 6, 2015, 321-346.

López MuÑoz, M. - InCLÁn García-Robés, L.: "Chiron, una propuesta didáctica para el siglo XXI”, Humanismo y pervivencia del mundo clásico V, vol.V 2763-2772.

Maquieira Rodríguez, H.: "Los nuevos grados de Filología Clásica en la Universidad española", Ianua Classicorum I 307-316.

Martos Fornieles, M.: "El palacio de Cnosos", Thamyris 6, 2015, 365-397.

Mestre, F. (ed.): Antologia. Selecció de textos grecs. D’Homer a Libani. Barcelona, Universidad de Barcelona, 2015.

Navarrete Orcera, A. R.: "El palacio Milzetti de Faenza (Rávena), una joya de la pintura mitológica", Thamyris 6, 2015, 423-439.

NAVArRo EsPaÑA, R.: "La enseñanza del griego antiguo: una clase con Athénaze", Thamyris 6, 2015, 5-16.

Navarro GonZÁlez, J. L.: "El griego en las P.A.U.", Ianua Classicorum I 295-305.

Navarro González, J. L. - Rodríguez Jiménez, J. M.: Aprender es Crecer en Conexión. Griego, 1 Bachillerato. Anaya, 2015.

Ndong Eseng, A. M. - Lacruz Martín, C.: Guía didáctica Griego. 1 bachillerato Madrid, Apyce, 2015.

- Guía didáctica Griego. 2 bachillerato Madrid, Apyce, 2015.

Riaño Riaño, J. I.: "Nuevos tiempos, nuevos métodos. El cine de griegos y romanos y su aplicación didáctica: Gladiator y 300", Ianua Classicorum I 347-354.

Robles, Rey, E.: "Una experiencia en el aula: repercusión de la mitología grecolatina en el Museo del Prado", Thamyris 6, 2015, 399-422.

Valverde García, A.: "Textos griegos anotados e ilustrados: de Homero a Apolonio de Rodas", Thamyris 6, 2015, 35-52 
